\title{
11. BIOGENIC SILICA AT ODP SITE 647 IN THE SOUTHERN LABRADOR SEA: OCCURRENCE, DIAGENESIS, AND PALEOCEANOGRAPHIC IMPLICATIONS ${ }^{1}$
}

\author{
Gerhard Bohrmann² and Ruediger Stein ${ }^{3}$
}

\begin{abstract}
Eocene to Holocene sediments from Ocean Drilling Program (ODP) Site 647 (Leg 105) in the southern Labrador Sea, approximately $200 \mathrm{~km}$ south of the Gloria Drift deposits, were investigated for their biogenic silica composition. Three sections of different diagenetic alteration products of primary siliceous components could be distinguished: (1) opal-A was recorded in the Miocene and the early Oligocene time intervals with strongly corroded siliceous skeletons in the Miocene and mostly well preserved biogenic opal in the early Oligocene; (2) opal-CT precipitation occurs between 250-440 meters below seafloor (mbsf) (earliest Oligocene to late Eocene); (3) between 620-650 mbsf (early/middle Eocene), biogenic opal was transformed to clay minerals by authigenesis of smectites. Using accumulation rates of biogenic opal, paleoproductivity was estimated for the early Oligocene to late Eocene interval. A maximum productivity of biogenic silica probably occurred between 35.5 and $34.5 \mathrm{Ma}$ (early Oligocene). No evidence for opal sedimentation during most of middle Eocene was found. However, at the early/middle Eocene boundary (around $52 \mathrm{Ma}$ ), increased opal fluxes were documented by diagenetic alteration products of siliceous skeletons.
\end{abstract}

\section{INTRODUCTION}

To reconstruct the early tectonic, paleoclimatic, and paleoceanographic evolution of the northeast Atlantic and Arctic oceans, three sites were drilled in Baffin Bay and Labrador Sea (Fig. 1) during ODP Leg 105 (Srivastava, Arthur, et al., 1987). Here, we investigate sediments from Site 647 , which is located about $200 \mathrm{~km}$ south of the Gloria Drift deposits in the southern Labrador Sea (latitude: $53^{\circ} 19.876^{\prime} \mathrm{N}$; longitude: $45^{\circ} 15.717^{\prime} \mathrm{W}$; water depth: $3862 \mathrm{~m})$. At Site 647 , a 699-m-thick sediment sequence of early Eocene to Holocene age was penetrated. At a depth of 699 mbsf, the basaltic basement was reached (Srivastava, Arthur, et al., 1987).

Our main interest in the sediments at Site 647 was the biogenic silica fraction. Next to calcite, opaline silica is the dominant material used by oceanic microorganism groups to construct their skeletons. Most siliceous tests are produced by diatoms, silicoflagellates, radiolarians, and, to a lesser extent, by benthic silica sponges. Since the present ocean environment is undersaturated everywhere with respect to silica (Calvert, 1974; Broecker and Peng, 1982), dissolution of this mineral phase occurs throughout. Nevertheless, biogenic opal is widely distributed in deep-sea sediments, and the abundance pattern of biogenic silica in surface sediments is closely related to the pattern of biogenic opal productivity (Lisitzin, 1972; Calvert, 1974; Leinen et al., 1986). Therefore, siliceous tests (i.e., their composition and abundance in deep-sea sediments) may be used to obtain information about paleoproductivity (e.g., Wolfart, 1982; Stein, 1985; Bohrmann, 1986). However, the amorphous mineral phase, opal-A, is widely unstable during diagenesis, and numerous diagenetic transformations to more stable silica phases are well known (e.g., Hein et al., 1978; Riech and von Rad, 1979;

\footnotetext{
${ }^{1}$ Srivastava, S. P., Arthur, M., Clement, B., et al., 1989. Proc. ODP, Sci. Results, 105: College Station, TX (Ocean Drilling Program).

2 Geologisch-Paläontologisches Institut und Museum der Christian-AlbrechtsUniversität zu Kiel, Olshausenstrasse 40, D-2300 Kiel, Federal Republic of Germany. Present address: Alfred-Wegener-Institut für Polar- und Meeresforschung, Columbusstraße, D-2850 Bremerhaven, Federal Republic of Germany,

${ }^{3}$ Institut für Geowissenchaften und Lithosphärenforschung, Universität Giessen, Senckenbergstrasse 3, 6300 Giessen, Federal Republic of Germany.
}

Kastner, 1980; Badaut and Risacher, 1983; Cole, 1985). Thus, biogenic silica studies concerning interpretations of paleoproductivity should take into account possible diagenetic alteration products of silica as well. The major objectives of this study on biogenic silica can be summarized as follows:

1. Changes in content, composition, and accumulation rates of biogenic opal through Eocene to Holocene time.

2. The influence of diagenesis on the distribution of biogenic silica (e.g., the transformation of opal-A $\rightarrow$ opal-CT $\rightarrow$ quartz).

3. Estimates of paleoproductivity in the Labrador Sea from biogenic silica content.

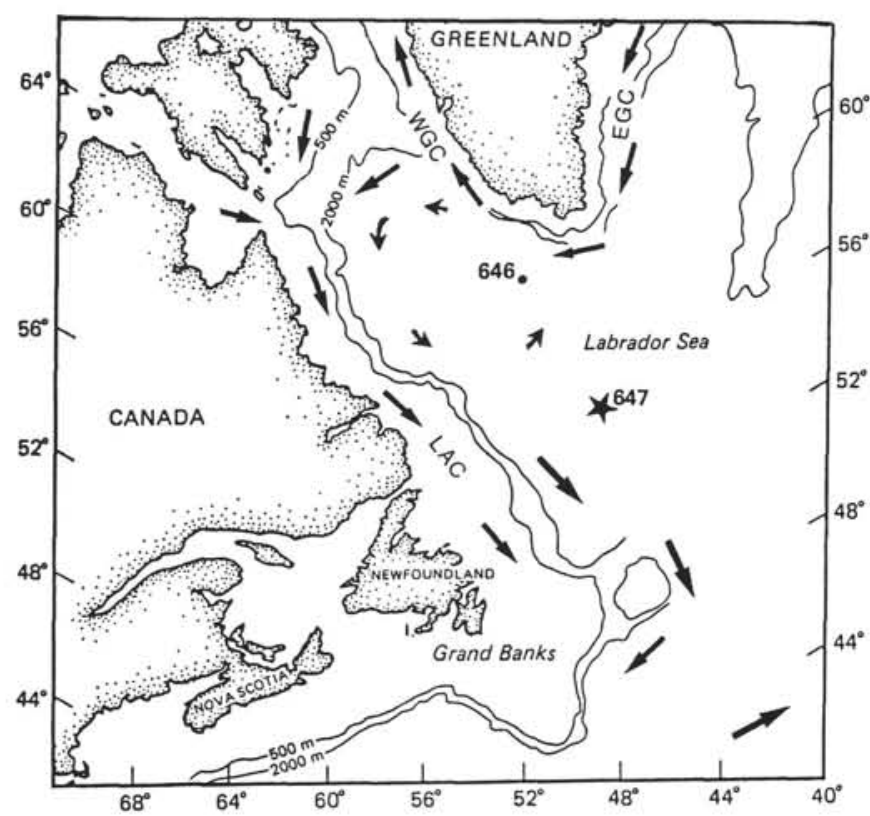

Figure 1. Position of ODP Site 647 ( $L A C=$ Labrador Current, $E G C=$ East Greenland Current, $W G C=$ West Greenland Current). 


\section{METHODS}

\section{Coarse Fraction Analysis}

Subsamples were treated with ammonia-buffered hydrogen peroxide solution to remove the organic matter and for better dispersion. Afterward, the samples were washed through a $63-\mu \mathrm{m}$ sieve. Both, the $<63$ $\mu \mathrm{m}$ and the $>63 \mu \mathrm{m}$ fraction were dried at $40^{\circ} \mathrm{C}$ and weighed for calculating the amount of coarse fraction. The $>63 \mu \mathrm{m}$ fraction was dry sieved into five subfractions. About 600 grains from a representative sample split of the $125-500 \mu \mathrm{m}$ fraction were counted to determine the composition of the coarse fraction.

\section{Organic and Inorganic Analyses}

After dissolution of the inorganic carbon fraction by hydrochloric acid, the carbonate-free residues were washed and dried. Then, the organic carbon content of the residues were measured using a CHN-analyzer. The organic values obtained by this procedure (i.e., total organic carbon $\left(\mathrm{TOC}^{\prime}\right)$ in weight percentage of the carbonate-free sediment fraction) were transferred into TOC values (weight percentage of the bulk sediment sample) using

$$
\text { TOC }=\frac{100-(8.334 \cdot \mathrm{TC})}{\left(100 / \mathrm{TOC}^{\prime}\right)-8.334},
$$

where TC is the total carbon in weight percentage of the bulk sediment, as determined by the $\mathrm{CHN}$-analyzer. The inorganic carbon (IC) was calculated by difference,

$$
\operatorname{IC}(\%)=\operatorname{TC}(\%)-\operatorname{TOC}(\%) .
$$

Then, the carbonate content was calculated as

$$
\mathrm{CaCO}_{3}(\%)=\mathrm{IC}(\%) \cdot 8.334 \text {. }
$$

\section{Opal Measurements}

Subsamples were treated with hydrogen peroxide and acetic acid to remove both organic matter and carbonate and to increase dispersion. The clay fraction $(<2 \mu \mathrm{m})$ was separated by the Atterberg method (Müller, 1967). After washing, the freeze dried $>2 \mu \mathrm{m}$ fraction was added to a sodium polytungstate solution $\left(3 \mathrm{Na}_{2} \mathrm{Wo}_{4} \cdot 9 \mathrm{Wo}_{3} \cdot \mathrm{H}_{2} \mathrm{O}\right)$. The density solution was adjusted at $2.25 \mathrm{~g} / \mathrm{cm}^{3}$. After density separation by centrifuge, both the lighter opal and the heavier non-opal fractions were washed several times with distilled water. After drying, the two fractions were weighted. The opal amount was calculated in weight percentage of the bulk sediment sample using the opal fraction separated in the density solution, then corrected by the carbonate content and the clay amount: arate).

Opal amount $=100-\left(\mathrm{CaCO}_{3}+\right.$ clay amount + heavy liquid sep-

Based on duplicates, the relative precision of this method was about $\pm 5 \%$ of the mean value in samples with more than $1 \%$ opal. However, the precision strongly depends on the extent of diagenetic habit. Cementing by authigenic silicates reduces the precision of this method (for details of this method see Bohrmann, 1988).

\section{X-Ray Diffraction Analyses}

X-Ray Diffraction (XRD) analyses were performed on bulk sediment samples and carbonate-free sediment fractions using a Siemens D 500 diffractometer ( $\mathrm{CuK} \alpha$ radiation). In some cases, additional measurements were performed on carbonate-free, $<2 \mu \mathrm{m}$ fractions using a Philips PW 1050 diffractometer (CoK $\alpha$ radiation). For XRD measurements of bulk sediment and carbonate-free sediment fractions, samples were ground and prepared as randomly oriented, pressed-powder slides. Scans were run between $5^{\circ}$ and $55^{\circ} 2 \theta$ using a scanning speed of $0.03^{\circ}$ $2 \theta / \mathrm{s}$. Calculation of intensity values of opal-CT and quartz was based on peak-area determination using a fully automatic separation of individual peaks (Lauterjung et al., 1985). Opal-CT was analyzed by the $\mathrm{d}(101)$ spacing of cristobalite (4.05-4.11 $\AA$ ) and the $\mathrm{d}(101)$ lattice of tridymite $(4.32 \AA)$ in the X-ray records. Because quartz is represented to higher extent in all samples, the T-peak can be seen only on the lower angle shoulder of the d(100) quartz peak $(4.26 \AA)$. Clay minerals were determined following Lange's method (1982).

\section{Microscopy}

Untreated sediment samples, coarse fraction samples, and opal fractions were mounted on scanning electron microscope (SEM) carriers. They were investigated using the SEM of the Geological Institute, Kiel (S150 Cambridge) at $10 \mathrm{kV}$, connected to an energy-dispersive X-ray spectrographic analyzer. Several thin sections and numerous smear slides were studied by light microscopy.

\section{Accumulation Rates}

As changes in the percentages of one component also may have resulted from changes in the other components present in the sediment, it is difficult to interpret percentages in terms of changes in supply of different components. Thus, the percentages were transformed into mass accumulation rates (MARs). Using these MARs, dilution effects by other components can be excluded. Furthermore, MARs take into account the compaction of sediment with increasing overburden and age and allow a comparison of sediment accumulation on both a temporal and areal basis. MARs were calculated according to van Andel et al. (1975), using linear sedimentation rates and dry-bulk density data from Leg 105 (Srivastava, Arthur, et al., 1987). Of course, these may differ somewhat on the basis of the final biostratigraphic determinations (Baldauf et al., this volume).

\section{RESULTS}

\section{General Characteristics and Lithologic Units at Site 647}

Four lithologic units were distinguished at Site 647 by the shipboard scientific party (Srivastava, Arthur, et al., 1987). Lithologic Unit I (0-116 mbsf; late Pliocene to Holocene) is dominantly characterized by clastic sediment types with variable amounts of biogenic pelagic particles and by low carbonate $(0 \%-40 \%)$ and low TOC values $(0.1 \%-0.5 \%$; Fig. 2$)$. The coarse fraction, which varies from $1 \%$ to $20 \%$ of the bulk sediment (Table 1) in this section, is composed mainly of calcareous biogenics (dominantly planktonic foraminifers) and siliciclastic components (mostly quartz, feldspar, mica, and rock fragments). Authigenic particles are of only minor importance. Both carbonate and lithogenic components may reach almost $100 \%$ of the coarse fraction (Fig. 2). High-amplitude variations are typical for the composition of the coarse fraction in the Pliocene-Pleistocene interval caused by glacial/interglacial fluctuations. Both the base and the top of lithologic Unit II (115-136 mbsf; Miocene) are marked by hiatuses (Srivastava, Arthur, et al., 1987). In this interval, carbonate and TOC values decrease to about $0 \%$ and to $0.1 \%$, respectively (Fig. 2). Several micronodules as well as widely distributed authigenic features document the higher diagenetic activity in this level. The sediments of this unit represent a condensed section, caused by either strong scour or nondeposition.

Lithologic Unit III (135-530 mbsf; early Oligocene to middle Eocene), characterized by higher amounts of biogenic sediment types, was divided into three subunits. The sediments of Subunits IIIA and IIIB are dominated by biogenic silica in the clay fraction, which shows maximum values of more than $70 \%$ in Subunit IIIB (Figs. 2 and 3). The carbonate values, which mostly represent variable amounts of calcareous nannofossils, are relatively high in Subunit IIIA $(20 \%-50 \%)$ and very low in Subunit IIIB (less than 10\%). TOC values vary between $0.2 \%$ and $0.5 \%$, the higher values of which are concentrated in Subunit IIIB (Fig. 2). Subunit IIIC is rich in calcareous nannofossils, documented by carbonate values ranging between $20 \%$ and $50 \%$. TOC values are between $0.1 \%$ and $0.4 \%$. The coarse fraction is dominated by benthic and planktonic foraminifers. In the upper part of Subunit IIIC, higher contents of authigenic components occur (Fig. 2). These particles are mostly pyrite-cemented burrow structures of variable diameters $(0.5-4 \mathrm{~mm})$.

The lowermost lithologic Unit IV (530-699 mbsf; middle to early Eocene) is characterized by claystone lithologies with low 


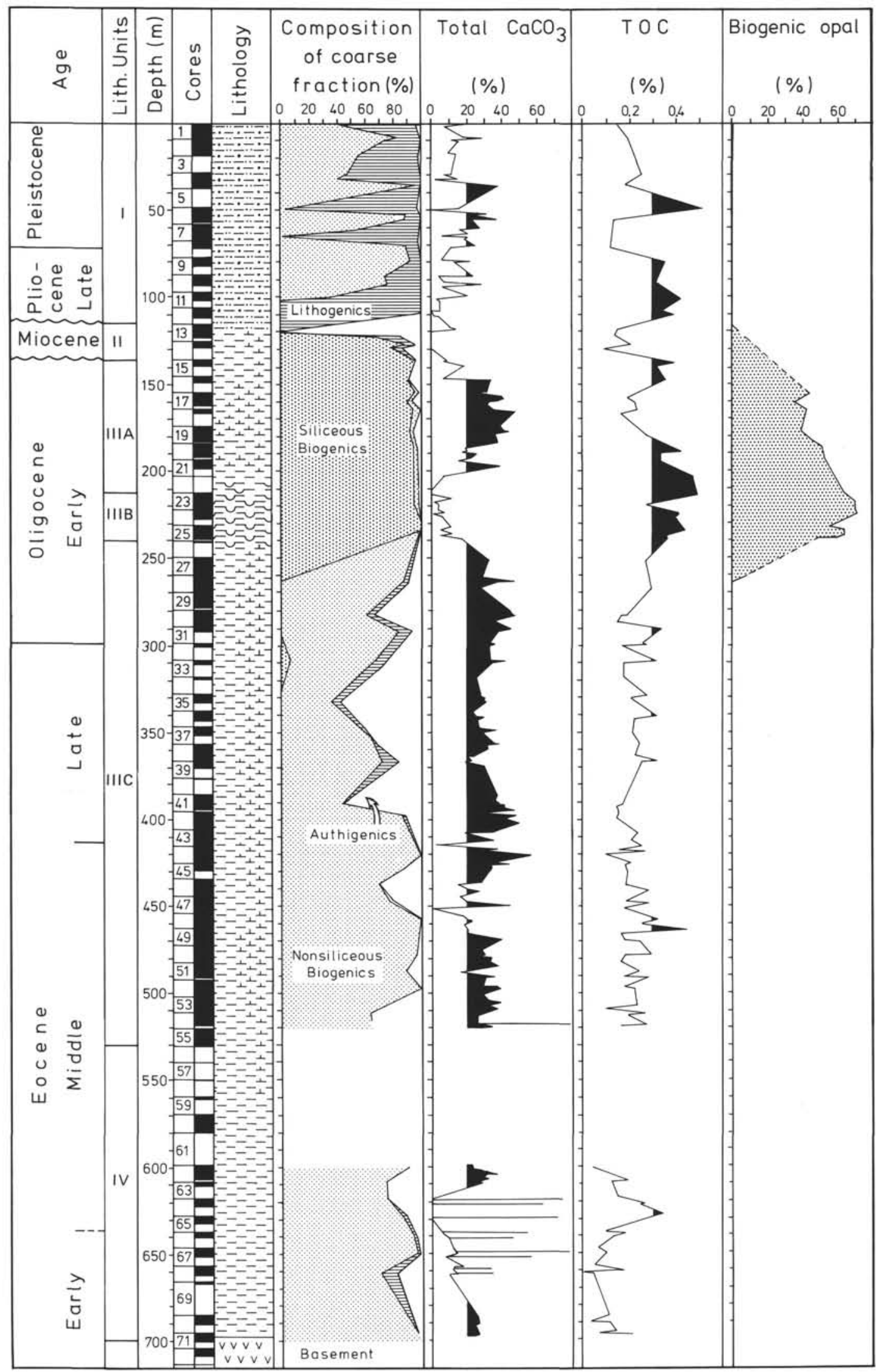

Figure 2. Summary of results, stratigraphy, lithologies, coarse fraction composition, carbonate and TOC contents, and amounts of biogenic opal. The carbonate and TOC records combine author data, shipboard data, data from Nielsen et al. (this volume), as well as Stein et al. (this volume). 
Table 1. Results of opal measurements, coarse fraction composition, and SEM observations.

\begin{tabular}{|c|c|c|c|c|c|c|c|c|}
\hline \multirow[b]{2}{*}{$\begin{array}{l}\text { Core/sample } \\
\text { interval }(\mathrm{cm})\end{array}$} & \multirow[b]{2}{*}{$\begin{array}{l}\text { Depth } \\
\text { (m) }\end{array}$} & \multirow{2}{*}{$\begin{array}{c}\text { Coarse } \\
\text { fraction } \\
(\%)\end{array}$} & \multicolumn{3}{|c|}{ Composition $>63 \mu \mathrm{m}$ frac. } & \multirow{2}{*}{$\begin{array}{c}\text { Opal } \\
\text { carb.-free } \\
(\%)\end{array}$} & \multirow{2}{*}{$\begin{array}{c}\text { Opal of } \\
\text { bulk sample } \\
(\%)\end{array}$} & \multirow[b]{2}{*}{$\begin{array}{c}\text { SEM } \\
\text { observations }\end{array}$} \\
\hline & & & $\begin{array}{l}\text { Sp. sp. } \\
(\%)\end{array}$ & $\begin{array}{l}\text { Rads. } \\
(\%)\end{array}$ & $\begin{array}{l}\text { Diat. } \\
(\%)\end{array}$ & & & \\
\hline $105-647 A-1 R-2,78$ & 2.28 & 5.32 & 0 & 0 & 0 & 0.01 & 0.01 & - \\
\hline 1R-6, 138 & 8.88 & 13.14 & 0 & 0 & 0 & 0.14 & 0.10 & - \\
\hline 2R-1, 98 & 10.18 & 8.06 & 0 & 0 & 0 & 0.05 & 0.04 & - \\
\hline $2 \mathrm{R}-6,134$ & 18.04 & 10.87 & 0 & 0 & 0 & 0.04 & 0.04 & - \\
\hline $4 \mathrm{R}-1,86$ & 29.46 & 8.87 & 0 & 0 & 0 & 0.01 & 0.01 & - \\
\hline $4 \mathrm{R}-3,74$ & 32.34 & 4.82 & 0 & 0 & 0 & 0.02 & 0.02 & - \\
\hline $4 \mathrm{R}-5,117$ & 35.77 & 16.21 & 0 & 0 & 0 & 0.03 & 0.02 & - \\
\hline $6 \mathrm{R}-1,93$ & 49.53 & 4.67 & 0 & 0 & 0 & 0.06 & 0.06 & - \\
\hline $6 \mathrm{R}-3,93$ & 52.53 & 14.85 & 0 & 0 & 0 & 0.01 & 0.01 & - \\
\hline $6 \mathrm{R}-5,93$ & 55.53 & 9.83 & 0 & 0 & 0 & 0.04 & 0.03 & - \\
\hline $7 \mathrm{R}-3,17$ & 61.47 & 3.94 & 0 & 0 & 0 & 0.02 & 0.02 & - \\
\hline $8 \mathrm{R}-2,52$ & 70.02 & 0.65 & 0 & 0 & 0 & 0.02 & 0.01 & - \\
\hline $9 \mathrm{R}-2,29$ & 79.39 & 5.31 & 0 & 0 & 0 & 0.04 & 0.03 & - \\
\hline $10 \mathrm{R}-1,42$ & 87.72 & 10.93 & 0 & 0 & 0 & 0.02 & 0.01 & - \\
\hline $10 \mathrm{R}-4,83$ & 92.63 & 14.18 & 0 & 0 & 0 & 0.07 & 0.05 & - \\
\hline $11 R-2,57$ & 99.07 & 5.43 & 0 & 0 & 0 & 0.07 & 0.05 & - \\
\hline $11 R-4,56$ & 102.06 & 20.29 & 0 & 0 & 0 & 0.07 & 0.07 & - \\
\hline $12 \mathrm{R}-1,79$ & 107.49 & 14.23 & 0 & 0 & 0 & 0.02 & 0.02 & - \\
\hline $12 \mathrm{R}-3,72$ & 110.42 & 18.05 & 0 & 0 & 0 & 0.07 & 0.07 & - \\
\hline $13 \mathrm{R}-1,64$ & 116.64 & - & - & - & - & 1.63 & 1.45 & Strongly corroded opal-A, clinoptilolite. \\
\hline $13 R-3,64$ & 119.64 & 0.04 & - & - & - & - & - & Strongly corroded opal-A, clinoptilolite. \\
\hline $13 R-5,64$ & 122.64 & 6.02 & 29.54 & 35.13 & 5.04 & - & - & Opal-A strongly corroded. \\
\hline $14 \mathrm{R}-1,64$ & 124.94 & 0.11 & 11.53 & 75.91 & 4.68 & - & - & Opal-A corroded. \\
\hline $14 \mathrm{R}-3,2$ & 128.72 & 0.45 & 19.95 & 55.64 & 4.68 & - & - & Opal-A corroded. \\
\hline $15 \mathrm{R}-1,62$ & 136.02 & 0.09 & 13.12 & 82.30 & 1.39 & - & - & Opal-A partly corroded. \\
\hline $16 \mathrm{R}-3,18$ & 148.28 & 0.25 & 5.36 & 83.73 & 2.24 & - & - & Opal-A partly corroded. \\
\hline $17 \mathrm{R}-1,51$ & 155.31 & 0.65 & 9.42 & 75.41 & 3.18 & 61.19 & 45.37 & Opal-A, good preservation. \\
\hline $17 \mathrm{R}-4,104$ & 160.34 & 0.16 & 3.11 & 70.51 & 17.76 & 57.88 & 36.39 & Opal-A good preservation. \\
\hline $18 \mathrm{R}-1,10$ & 165.11 & 0.03 & 7.36 & 83.74 & 6.44 & 68.10 & 43.75 & Opal-A, good preservation. \\
\hline $19 \mathrm{R}-3,49$ & 177.29 & 0.02 & 9.39 & 62.50 & 12.01 & 69.94 & 39.98 & Opal-A, good preservation. \\
\hline $20 \mathrm{R}-3,42$ & 186.92 & 0.02 & 10.62 & 71.95 & 13.93 & 65.85 & 52.32 & Opal-A, good preservation. \\
\hline $21 R-1,26$ & 193.36 & - & - & - & - & 69.33 & 53.79 & Opal-A, good preservation. \\
\hline $23 \mathrm{R}-1,19$ & 212.59 & - & - & - & - & 64.77 & 64.38 & Opal-A, good preservation. \\
\hline $23 \mathrm{R}-4,118$ & 217.98 & - & - & - & - & 72.36 & 70.53 & Opal-A, good preservation, Pyxilla dominant. \\
\hline $23 R-5,79$ & 219.09 & 0.47 & 5.12 & 83.21 & 7.92 & 75.28 & 71.24 & Opal-A, good preservation, Pyxilla dominant. \\
\hline $24 \mathrm{R}-1,51$ & 222.41 & - & - & - & - & 74.38 & 70.97 & Opal-A, good preservation, Pyxilla dominant. \\
\hline $24 \mathrm{R}-2,12$ & 224.68 & 0.02 & 12.03 & 64.97 & 11.86 & 71.83 & 71.83 & Opal-A, good preservation, Pyxilla dominant. \\
\hline $24 \mathrm{R}-4,52$ & 226.92 & 0.03 & 10.17 & 72.13 & 7.00 & 72.25 & 67.25 & Opal-A, good preservation. \\
\hline $25 \mathrm{R}-1,56$ & 232.06 & - & - & - & - & 64.68 & 56.86 & Opal-A, good preservation. \\
\hline $25 \mathrm{R}-2,68$ & 233.68 & 0.26 & 6.07 & 73.29 & 20.44 & 69.02 & 64.89 & Opal-A partly corroded. \\
\hline $25 \mathrm{R}-4,95$ & 236.95 & - & - & - & - & 68.85 & 64.73 & Opal-A partly corroded. \\
\hline $25 \mathrm{R}-5,145$ & 238.95 & - & - & - & - & 61.37 & 50.38 & Opal-A partly corroded. \\
\hline $28 \mathrm{R}-3,92$ & 264.02 & 0.02 & 0.00 & 0.00 & 0.00 & 0.85 & 0.52 & Opal-A corroded. \\
\hline $30 \mathrm{R}-3,30$ & 282.71 & 0.02 & 0.00 & 0.00 & 0.00 & - & - & Opal-A corroded. \\
\hline $31 \mathrm{R}-2,53$ & 291.03 & - & - & - & - & - & - & Opal-CT, irregular lepispheres. \\
\hline $31 \mathrm{R}-2,58$ & 292.08 & 0.04 & 2.08 & 0.00 & 0.00 & 0.29 & 0.18 & Opal-CT, irreg. lepispheres; rads, replaced. \\
\hline $32 \mathrm{R}-1,26$ & 298.86 & - & - & - & - & 0.04 & 0.03 & Opal-CT, lepispheres. \\
\hline $32 \mathrm{R}-2,38$ & 300.38 & - & - & - & - & - & - & Opal-CT, lepispheres. \\
\hline $33 \mathrm{R}-1,64$ & 308.94 & 0.05 & 0 & 7.33 & 0 & 0.27 & 0.18 & Opal-CT, irreg. lepispheres; rads, replaced. \\
\hline $33 \mathrm{R}-2,95$ & 310.39 & - & - & - & - & - & - & Opal-CT, irregular lepispheres. \\
\hline $35 \mathrm{R}-4,31$ & 332.41 & 0.04 & 0 & 0 & 0 & 0.05 & 0.03 & Opal-CT, irregular lepispheres. \\
\hline $64 \mathrm{R}-1,39$ & 617.89 & - & - & - & - & - & - & Diatoms and radiolarians replaced by smectites. \\
\hline $64 \mathrm{R}-1,48$ & 617.98 & - & - & - & - & - & - & Diatom (opal-A) strongly corroded. \\
\hline $64 \mathrm{R}-3,65$ & 621.35 & - & - & - & - & - & - & Ghosts of biogenic opal preserved as smectites. \\
\hline $66 \mathrm{R}-1,54$ & 637.33 & - & - & - & - & - & - & Ghosts of biogenic opal preserved as smectites. \\
\hline $66 \mathrm{R}-3,40$ & 640.20 & - & - & - & - & - & - & Diatom (opal-A) strongly corroded. \\
\hline $67 R-2,48$ & 648.47 & - & - & - & - & - & - & Ghosts of biogenic opal preserved as smectites. \\
\hline $68 \mathrm{R}-1,95$ & 657.74 & - & - & - & - & - & - & Ghosts of biogenic opal preserved as smectites. \\
\hline
\end{tabular}

carbonate values (most of which are less than $15 \%$ ) and TOC values ranging between $0 \%$ and $0.3 \%$ (Fig. 2). Authigenic carbonate concretions occur at 320 to 665 mbsf and show carbonate contents of up to $80 \%$ (Fig. 2; Bohrmann and Thiede, this volume; Arthur et al., this volume). The coarse fraction of sediments from Unit IV is composed of mostly siliceous benthic and calcareous planktonic foraminifers and authigenic particles (Fig. 2).

\section{Distribution and Composition of Opaline Silica at Site 647}

In general, the measured opal concentrations are very low (lower than $0.1 \mathrm{wt} \%$ ) in lithologic Unit I (Table 1). Only scat- tered corroded sponge spicules and radiolarians are observed in smear slides. Higher amounts of biogenic opal are restricted to Units II, IIIA, and IIIB (i.e., Cores 105-647A-13R through -25R; Figs. 2 and 4). However, opal contents could not be measured in Cores 105-647A-13R through -16R, using our method of determining opal contents, because of the high degree of diagenetic alteration in this level. This diagenetic alteration occurred in association with significant hiatuses in Cores 105647A-13R and 105-647A-15R (Srivastava, Arthur, et al., 1987) However, smear slides show a progressive increase downcore in opaline silica amounts, combined with a decrease in corrosion features. This pattern also seems to be documented by the distribution of siliceous skeletons in the coarse fraction (Fig. 3 and Baldauf and Montjanel, this volume; see also Lazario and $\mathrm{Pa}$ - 

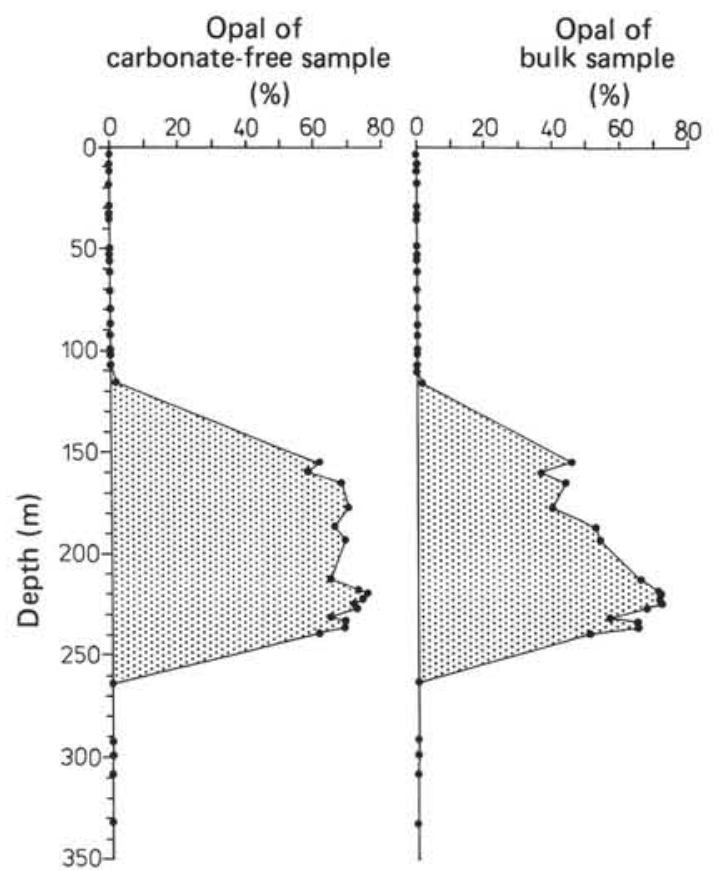

\section{Coarse fraction components Sponge Spicules} (\%)

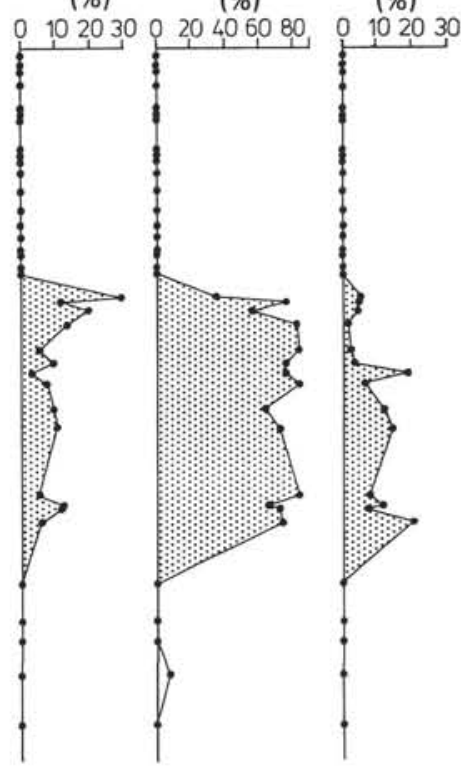

Figure 3. Opal contents from carbonate-free and bulk sediment samples and opal composition of the coarse fraction.

seant, this volume). Sponge spicules, which are especially resistant to dissolution, seem to be concentrated by loss of the less-resistant diatoms and radiolarians in the upper part, then decrease downward. Parallel to the decrease in sponge spicules, the content of less dissolution-resistant radiolarians and diatoms increases (Fig. 3).

In Unit IIIA, between 150 and 200 mbsf, constant high opal contents ranging from $35 \%$ to $50 \%$ were reached in the sediments. In Unit IIIB, between 200-235 mbsf, opal concentrations exceed values of $60 \%$ with an absolute maximum around $217-225$ mbsf, revealing more than $70 \%$ opal of the bulk sediment.

A comparison of the opal content of the carbonate-free sediment fraction and the opal content of the bulk sample (Fig. 3) documents the dilution effect of biogenic carbonate in the upper part of Unit III. The regional seismic reflector R3, at about 220 mbsf $(0.24 \mathrm{~s})$, seems to represent this change from carbonate-rich siliceous sediments above to carbonate-poor diatom oozes below (Srivastava, Arthur, et al., 1987; Arthur et al., this volume).

The measured opal contents agree well with the amounts of siliceous skeletons in the coarse fraction (Fig. 3). Radiolarians are the most dominant opaline component in the $>63 \mu \mathrm{m}$ fraction (Pl. 1, Fig.4; Pl. 2, Fig. 4). However, the coarse fraction is only a small percentage of the bulk sediment (Table 1), and on average, the smaller diatom frustules dominate the whole bulk opal fraction (Pl. 2, Fig. 3). Smear slide samples between 217 and 224 mbsf reveal that the opal fraction is composed dominantly of elongated diatom frustules (Pl. 2, Figs. 1 and 2) of the genus Pyxilla (see also Baldauf and Monjanel, this volume). In thin sections we observed that the longish valves are well oriented parallel to stratification (Pl. 1, Fig. 3). The elongated valves, with lengths of 70 to $140 \mu \mathrm{m}$, a broad end at the base (10-20 $\mu \mathrm{m}$ in diameter), and a smaller apical end (5-10 $\mu \mathrm{m})$, seem to be of a shape that may have been oriented during bottom-current activity. However, orientation pattern in single layers could not be observed on bedding surfaces in SEM samples.
The lack of orientation of the valves implies they were not transported by bottom currents, but rather were deposited directly beneath a region of high surface productivity. Pyxilla dominates in sediment samples where maxima in biogenic opal concentrations are observed.

Opal concentrations decrease from a high level of $>70 \%$ (Fig. 3) to very low level $(<1 \%)$ below 240 mbsf. The prominent regional seismic reflector R4 at about that depth (Srivastava, Arthur, et al., 1987; Arthur et al., this volume) seems to define this lower limit of opal-rich sediment types. With some exceptions, opal-A-preserved biogenics disappear from Core 105647A-35R downhole. Only some poorly preserved, mostly fragmented, recrystallized or pyriticized siliceous biogenic remnants were found.

\section{Mass Accumulatiom Rates}

The MAR of the bulk sediment and the carbonate, TOC, and biogenic silica fractions are shown for the early Oligocene to early Eocene time interval (Subunits III and IV) in Figure 5. This time interval can be divided into four sections by MARs:

1. The early Oligocene ( 34.5 to $30.5 \mathrm{Ma}$ ) is characterized by low bulk MAR of around $1000 \mathrm{~g} / \mathrm{cm}^{2} / \mathrm{m}$.y. Carbonate MARs vary between 100 and $600 \mathrm{~g} / \mathrm{cm}^{2} / \mathrm{m}$.y. TOC and biogenic opal MARs are relatively constant, reaching values of about 5 and $500 \mathrm{~g} / \mathrm{cm}^{2} / \mathrm{m}$.y., respectively (Fig. 5).

2 . In the earliest Oligocene, the bulk MARs show a two-step increase downcore. Between 35.5 and $34.5 \mathrm{Ma}$, MAR increases to values of about 2000 to 2500 , followed by an increase of about $4000 \mathrm{~g} / \mathrm{cm}^{2} / \mathrm{m}$.y. at $35.5 \mathrm{Ma}$. The first increase is also recorded in the TOC and biogenic opal MAR, whereas the carbonate MAR remains low (Fig. 5). Between 35.2 and $34.5 \mathrm{Ma}$, biogenic opal MARs reach their maximum of about $1500 \mathrm{~g} /$ $\mathrm{cm}^{2} / \mathrm{m}$.y. (Fig. 5). The second increase in bulk MAR at about $35.5 \mathrm{Ma}$ is also shown by the carbonate record, whereas the TOC curve remains relatively constant and the biogenic opal values distinctly decrease (Fig. 5). The decrease in biogenic opal 


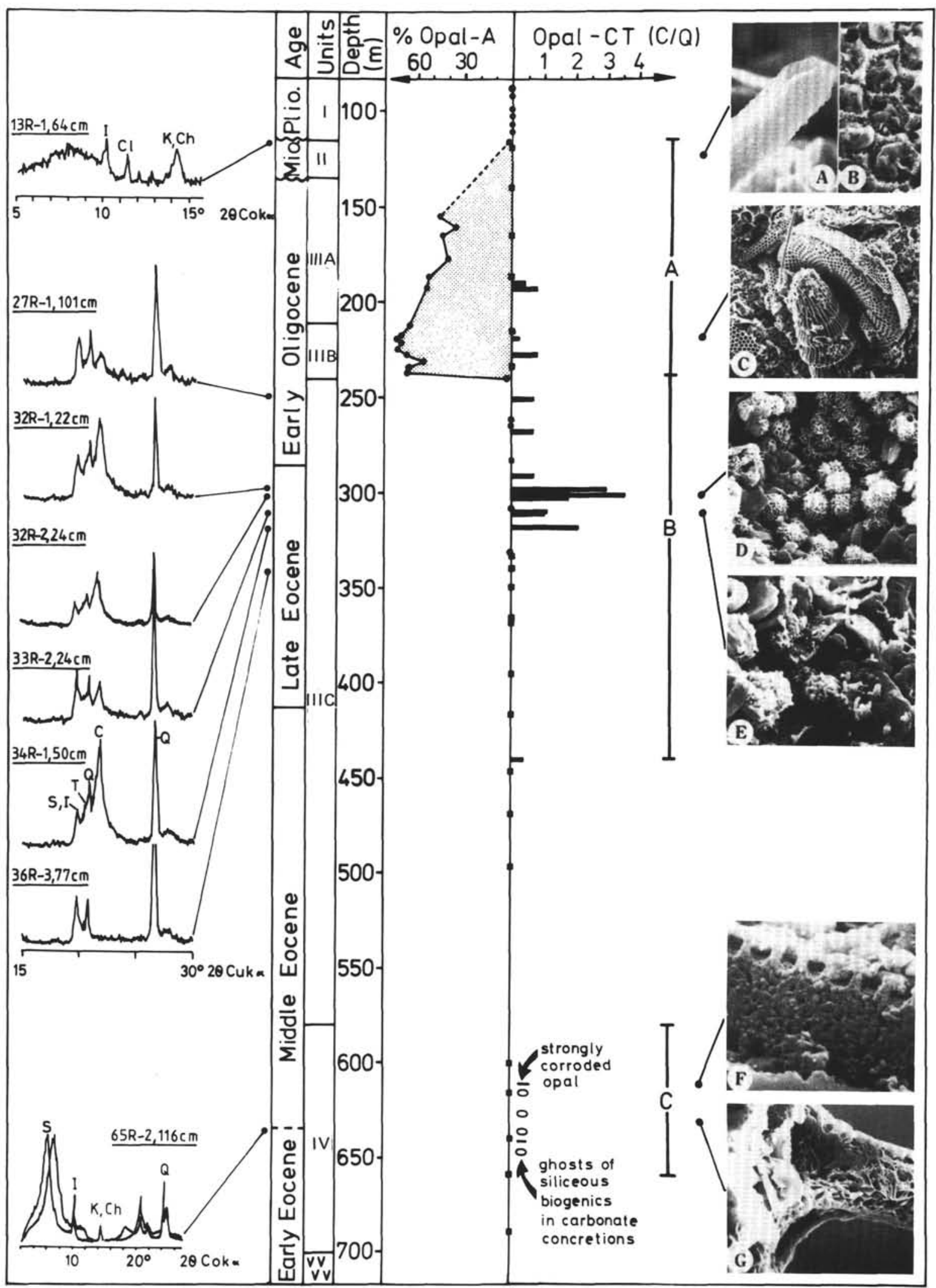

Figure 4. Abundance of opal-A and opal-CT (expressed by XRD peak-area ratio of cristobalite and quartz) and diagenetic sections of opaline silica (A, B, and C) at Site 647. Left column shows examples from X-ray records. $I=I l$ lite, $C l=C$ linoptilolite, $K$ $=$ Kaolinite, $C h=$ Chlorite, $S=$ Smectite, $Q=$ Quartz, $C=$ Cristobalite, $T=$ Tridymite. Right column shows SEM pictures: A. Strongly dissolved diatom; B. Corroded clinoptilolite; C. Well-preserved opal-A; D. Well-developed opal-CT lepispheres; E. Irregular opal-CT blades; F. strongly corroded opal-A; G. Authigenic smectites pseudomorphic to a radiolarian skeleton. 


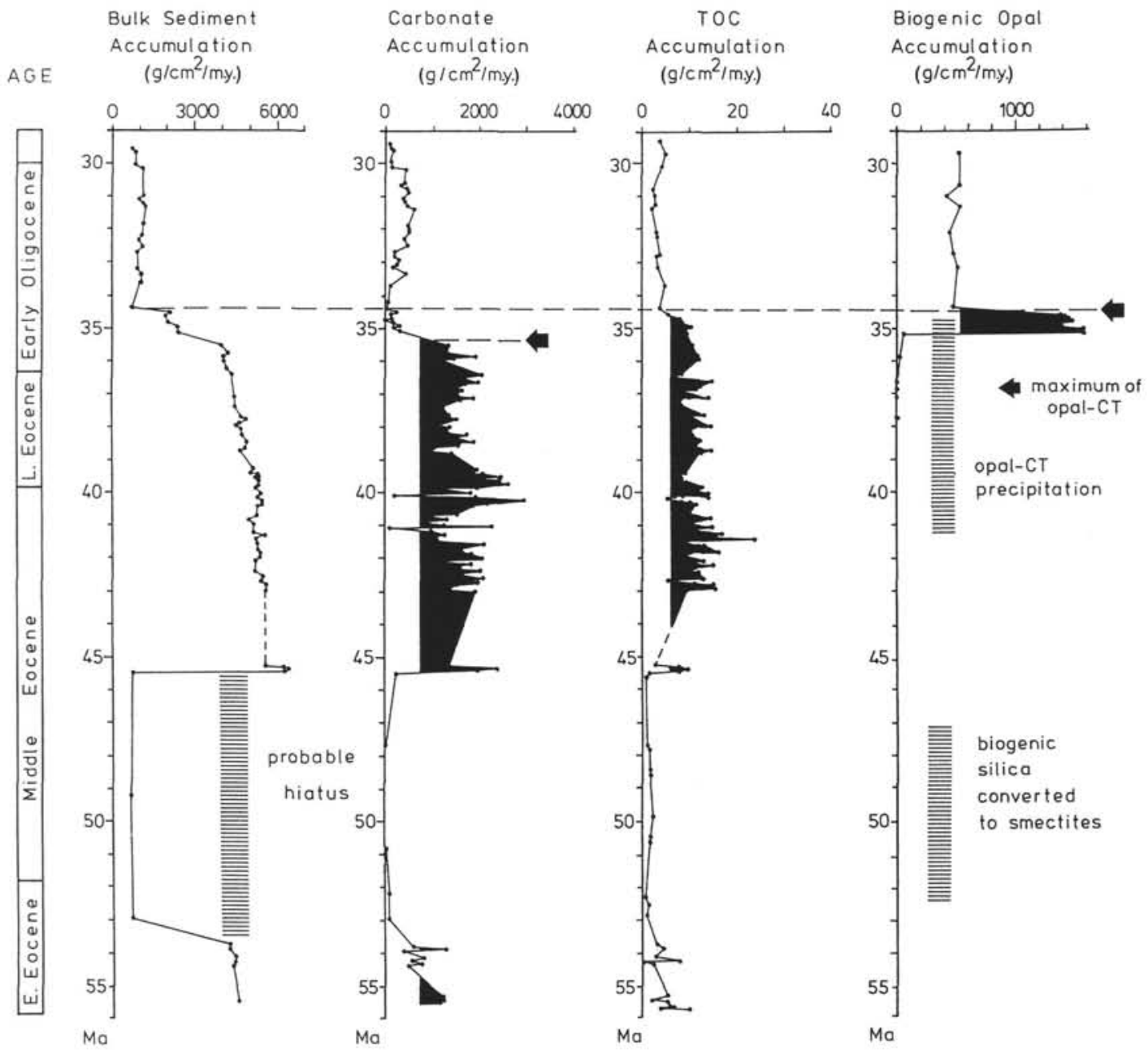

Figure 5. Accumulation rates of bulk sediment, carbonate, total organic carbon, and biogenic opal vs. age (29.5 to $55.2 \mathrm{Ma})$.

coincides with the increase in opal-CT precipitation (Figs. 4 and 5).

Between 39.5 and $35.5 \mathrm{Ma}$ (i.e., during late Eocene), the bulk MAR continually increases from 4000 to about $5300 \mathrm{~g} /$ $\mathrm{cm}^{2} / \mathrm{m}$.y., followed by a period of relatively constant values of about 5300 to $5500 \mathrm{~g} / \mathrm{cm}^{2} / \mathrm{m}$.y. between $43.2(45.2)$ and 39.5 Ma, i.e., in upper middle Eocene. Maximum bulk MAR occurs at about $45.5 \mathrm{Ma}$ (about $6200 \mathrm{~g} / \mathrm{cm}^{2} / \mathrm{m}$.y.; Fig. 5).

3. The interval at about 53.5 and $45.5 \mathrm{Ma}$ (i.e., [early] middle to [late] early Eocene) is characterized by extremely low bulk MARs (less than $600 \mathrm{~g} / \mathrm{cm}^{2} / \mathrm{m}$.y.; Fig. 5). These low MARs coincide with the interval where increased transformation of biogenic silica into smectites occurs (see discussion of diagenesis). However, this interval of sedimentation is extremely condensed, and $\mathrm{CaCO}_{3}$ nearly completely dissolved; a hiatus also may possibly be present, thereby compromising the calculated MAR values.

4. In the lowermost interval investigated (i.e., 55.5 to 53.5 $\mathrm{Ma}$ ), bulk MAR increases to values of about $4300 \mathrm{~g} / \mathrm{cm}^{2} / \mathrm{m}$.y. (Fig. 5). If the presence of a hiatus caused by bottom-current erosion near $45.5 \mathrm{Ma}$ is true (Bohrmann and Thiede, this volume), the bulk MAR originally may have been similarly high throughout the time interval between 55.5 and $35.5 \mathrm{Ma}$ (i.e., between about 4300 and $5300 \mathrm{~g} / \mathrm{cm}^{2} / \mathrm{m}$.y.

\section{DIAGENESIS OF BIOGENIC OPAL}

Investigations of the diagenesis of opaline silica at ODP Site 647 revealed that different mineralogical alteration products occur. For discussion of this subject, it is useful to distinguish three main sections (A, B, and C) that are characterized by different conditions of biogenic silica preservation and related alteration products. The three sections are outlined in Figure 4, where characteristic SEM pictures and X-ray records are shown as well.

\section{Section A}

In Section A, all sediments containing higher amounts of opaline silica are summarized (Units II, IIIA, IIIB; 120-240 mbsf; Fig. 4). The opal-A preservation is of variable quality. Strong corrosion is widely distributed in Cores 105-647A-13R through $-15 R$. Strongest dissolution occurs in Core 105-647A$13 \mathrm{R}$ and 105-647A-14R of lithologic Unit II. Diatoms are mostly fragmented (Pl. 1, Fig. 2) and surface corrosion was observed on almost all silica components. Most siliceous particles show very fine globulose structures of microspheres, which seem to be ultrastructural elements of skeletal opal well revealed by surface dissolution (Pl. 1, Fig. 1). In Core 105-647A-13R, two samples containing clinoptilolite were recorded by XRD, smear slides, 
and SEM observations (Fig. 4), indicating in-situ growth of authigenic zeolites following dissolution of biogenic opal-A. In SEM samples, the zeolite crystals also show strongly edged surface structures (Fig. 4).

Partly corroded opal fractions can be seen in Core 105-647A$16 \mathrm{R}$ and below 240 mbsf, whereas in the interval between 150 240 mbsf biogenic silica is mainly well preserved.

\section{Section B}

Section B is characterized by a rapid decrease of opal-A combined with stronger opal dissolution and higher amounts of opal-CT (Fig. 4), although opal-CT is present in minor amounts in Section A. To document the variability of opal-CT content, we have plotted the ratio of cristobalite and quartz peak intensities $(\mathrm{C} / \mathrm{Q})$ in Figure 4 and Table 2. In general, opal-CT peaks are detectable between 190 and 440 mbsf. However, higher amounts of opal-CT are found in Cores 105-647A-32R through -34R (298-320 mbsf), with maximum concentrations recorded in Core 105-647A-32R at approximately 300 mbsf.

In SEM studies we found opal-CT only in Cores 105-647A$31 \mathrm{R}$ through $-34 \mathrm{R}$. The opal-CT was generally developed as vermiculelike blades $(0.1 \mu \mathrm{m}$ thick) that formed irregular lepispheres of variable size (mostly 1-3 $\mu$ m diameter; Pl. 4, Fig. 3). Such spheres of blades scarcely show the tridymite-type twinning (Flörke et al., 1975). The origin of opal-CT precipitation from silicon-rich solutions is well documented as lepispheres have grown in the remaining pore space on the surface (Pl. 4, Fig. 2), mostly at connecting points of sediment particles such as coccoliths (Pl. 4, Figs. 1 and 3). The sediment samples of Core 105-647A-32R contain higher amounts of more densely packed opal-CT lepisheres grown in larger cavities, such as foraminiferal tests (Pl. 3, Figs. 1 and 2). There, the lepispheres show larger opal-CT blades intergrown according to the twinning laws of tridymite (Riech and von Rad, 1979). The $0.1-\mu$ m-thick blades of the spheres reveal typical irregularly ragged edges (PI. 3, Fig. 2). Radiolarians with in-situ replacement of the opal-A skeletons by opal-CT also were observed (Pl. 3, Fig. 3). These pseudomorphs show a more or less irregular network of the vermiculelike type of opal-CT blades on its surface (Pl. 3, Fig. 4). Since silicification of the clayey nannofossil chalks and nannofossil claystones is of minor extent, the fine sediment matrix between coarser sediment particles does not seem to be composed of dense masses of opal-CT, as is well known from porcelanitic sediments (Riech and von Rad, 1979).

\section{Section C}

This sediment section, restricted to lithologic Unit IV, is characterized by a widely distributed transformation of biogenic opal to authigenic smectites. SEM investigations from claystones revealed only two samples (105-647A-64R-1, $95 \mathrm{~cm}$, and $105-647 \mathrm{~A}-66 \mathrm{R}-3,70 \mathrm{~cm}$ ) of very poorly preserved diatoms (Fig. 4; Pl. 4, Fig. 4). The specimen shows fine globulose surface structures of microspheres. Such features are different from opal-CT and quartz and are well known from other examples strong dissolution of opal-A tests. Therefore, we assume that a minor amount of siliceous particles still consists of amorphous, strongly altered opal-A. Apart from the rarely preserved diatoms, numerous ghosts of siliceous biogenics (Pl. 5, Fig. 1) are found in early cemented carbonate concretions (Bohrmann and Thiede, this volume). The originally opaline skeletons were replaced by authigenic smectites (Pl. 5, Figs. 2 through 4). Detailed microscopic analyses indicate that iron-rich smectite formation took place after a first carbonate generation had been precipitated. Thus, the skeletal morphology of the siliceous tests was preserved in these early carbonate concretions, whereas outside, only smectites were found without remnants of biogenics. Bohrmann and Thiede (this volume) postulate smectite forma-
Table 2. Results of X-ray diffraction analyses (peak area of minerals).

\begin{tabular}{|c|c|c|c|c|c|}
\hline $\begin{array}{l}\text { Core/sample } \\
\text { interval }(\mathrm{cm})\end{array}$ & $\begin{array}{c}\text { Depth } \\
\text { (m) }\end{array}$ & $\begin{array}{c}\text { Cristobalite } \\
\text { d(101) } \\
(4.05-4.11 \AA)\end{array}$ & $\begin{array}{c}\text { Tridymite } \\
\text { d(101) } \\
(4.32 \AA)\end{array}$ & $\begin{array}{l}\text { Quartz } \\
\text { d(100) } \\
(4.26 \AA)\end{array}$ & $\begin{array}{l}\mathrm{C} / \mathrm{Q} \\
\text { ratio }\end{array}$ \\
\hline $105-647$ A-2R-6, 55 & 17.25 & - & - & 1444 & 0 \\
\hline $4 R-5,75$ & 35.35 & - & - & 1282 & 0 \\
\hline $6 R-5,70$ & 55.30 & - & - & 947 & 0 \\
\hline $9 \mathrm{R}-1,77$ & 78.37 & - & - & 2307 & 0 \\
\hline $11 \mathrm{R}-3,80$ & 100.80 & - & - & 2813 & 0 \\
\hline $13 R-3,76$ & 119.76 & - & - & 1385 & 0 \\
\hline $15 \mathrm{R}-3,70$ & 139.10 & - & - & 729 & 0 \\
\hline $18 \mathrm{R}-2,93$ & 166.53 & - & - & 428 & 0 \\
\hline $19 \mathrm{R}-5,100$ & 180.81 & - & 252 & 776 & 0 \\
\hline $20 \mathrm{R}-3,48$ & 186.98 & - & - & 862 & 0 \\
\hline $20 \mathrm{R}-4,119$ & 189.19 & 521 & 380 & 1474 & ${ }^{\mathrm{a}} 0.4$ \\
\hline $20 \mathrm{R}-4,119$ & 189.19 & - & 361 & 954 & 0 \\
\hline $21 \mathrm{R}-1,90$ & 194.00 & 788 & 251 & 1045 & 0.8 \\
\hline $23 \mathrm{R}-3,91$ & 216.21 & - & - & 983 & 0 \\
\hline $23 \mathrm{R}-5,49$ & 218.79 & 264 & 235 & 897 & 0.3 \\
\hline $24 \mathrm{R}-3,101$ & 226.01 & 972 & - & 1128 & 0.9 \\
\hline $25 \mathrm{R}-3,136$ & 235.86 & 459 & - & 1424 & 0.3 \\
\hline $25 \mathrm{R}-1,68$ & 233.68 & - & - & 1196 & 0 \\
\hline 27R-1, 101 & 251.41 & 1900 & - & 2675 & ${ }^{a} 0.7$ \\
\hline $28 \mathrm{R}-3,90$ & 264.00 & - & - & 512 & 0 \\
\hline $28 \mathrm{R}-4,20$ & 264.74 & 440 & 247 & 773 & 0.6 \\
\hline $30 \mathrm{R}-3,32$ & 282.73 & - & - & 667 & 0 \\
\hline $31 \mathrm{R}-2,53$ & 291.03 & 734 & 467 & 981 & 0.7 \\
\hline $32 \mathrm{R}-1,22$ & 298.82 & 3298 & 788 & 1109 & 3 \\
\hline $32 \mathrm{R}-1,22$ & 298.82 & 8448 & 1162 & 1800 & $a_{4.6}$ \\
\hline $32 \mathrm{R}-1,25$ & 298.85 & 1400 & 266 & 768 & 1.8 \\
\hline $32 \mathrm{R}-2,24$ & 300.34 & 2237 & 712 & 601 & 3.7 \\
\hline $32 \mathrm{R}-2,38$ & 300.48 & 4469 & 1041 & 2486 & $a_{1.8}$ \\
\hline $33 \mathrm{R}-1,96$ & 309.26 & 970 & 539 & 835 & 1.1 \\
\hline $33 \mathrm{R}-1,96$ & 309.26 & 2289 & 527 & 2285 & ${ }^{a} 1.0$ \\
\hline $33 R-2,59$ & 310.39 & 1038 & 350 & 1024 & 1.0 \\
\hline $34 \mathrm{R}-1,50$ & 318.50 & 6629 & 1245 & 3217 & ${ }^{a} 2.1$ \\
\hline $35 \mathrm{R}-4,30$ & 332.40 & 0 & 0 & 964 & 0 \\
\hline $36 R-3,77$ & 340.97 & 0 & 0 & 1369 & 0 \\
\hline $36 \mathrm{R}-3,77$ & 340.97 & 0 & 168 & 1494 & ${ }^{\mathrm{a}} 0$ \\
\hline $37 \mathrm{R}-3,79$ & 350.49 & 0 & 0 & 2419 & ${ }^{\mathrm{a}} 0$ \\
\hline $39 \mathrm{R}-1,56$ & 366.66 & 0 & 0 & 1383 & 0 \\
\hline $39 \mathrm{R}-1,99$ & 367.09 & 0 & 107 & 3759 & ${ }^{a} 0$ \\
\hline $42 \mathrm{R}-1,64$ & 395.74 & 0 & 0 & 1582 & 0 \\
\hline $44 \mathrm{R}-3,9$ & 417.49 & 0 & 0 & 1432 & 0 \\
\hline $46 \mathrm{R}-5,106$ & 440.86 & 400 & 251 & 1176 & ${ }^{\mathrm{a}} 0.3$ \\
\hline $47 \mathrm{R}-3,53$ & 447.03 & 0 & 0 & 1487 & 0 \\
\hline $49 \mathrm{R}-5,113$ & 469.93 & 0 & 0 & 1547 & 0 \\
\hline $52 \mathrm{R}-4,105$ & 497.35 & 0 & 0 & 1771 & 0 \\
\hline $62 \mathrm{R}-3,26$ & 601.36 & 0 & 0 & 1565 & 0 \\
\hline $64 \mathrm{R}-1,49$ & 617.99 & 0 & 0 & 1557 & 0 \\
\hline $66 \mathrm{R}-3,41$ & 640.21 & 0 & 0 & 1832 & 0 \\
\hline $68 \mathrm{R}-4,5$ & 660.75 & 0 & 0 & 2558 & 0 \\
\hline 70R-3, 119 & 689.39 & 0 & 0 & 4831 & 0 \\
\hline
\end{tabular}

${ }^{\mathrm{a}}$ Analyses on carbonate-free samples.

tion analogous to processes described for eastern equatorial $\mathrm{Pa}$ cific sediments (Heath and Dymond, 1977; Cole, 1985). The smectites were probably formed as a low-temperature combination of iron oxyhydroxide and biogenic silica. The biogenic opal provides a substrate for authigenic growth of nontronitic smectites. This process seems to have occurred at Site 647, mainly in sediments of early and middle Eocene age.

\section{DISCUSSION}

\section{Influence of Diagenesis on the Distribution of Biogenic Opal}

A great portion of biogenic opal-A originally incorporated into the sediment record was dissolved or replaced owing to its amorphous unstable mineralogy. In Section A, dissolution occurs between 120 and 150 mbsf. Low sedimentation rates kept siliceous tests exposed to undersaturated, corrosive pore waters longer than tests deposited during times of higher sedimentation rates. The result was strong dissolution of siliceous parti- 
cles. Zeolite precipitation (clinoptilolite) was also found in Core 105-647A-13R; the silicon could be derived from dissolved opal (see Fenner, 1981; Stein, 1985; Thein and von Rad, 1987).

A second silicate mineral precipitation is the opal-CT formation starting at approximately $190 \mathrm{mbsf}$, where high concentrations of opal-A are still present. The maximum of opal-A to opal-CT transformation is developed in a depth of about 300 mbsf, where no more opal-A was found. It is well known from numerous DSDP sites (e.g., Riech and von Rad, 1979; Hein et al., 1978; Thein and von Rad, 1987) that silica diagenesis proceeds as a maturation from opal-A $\rightarrow$ opal- CT $\rightarrow$ quartz. This diagenetic transformation from unstable to stable mineral phases is influenced by time, burial depth, temperature, and host rock facies (Riech and von Rad, 1979). Opal-CT precipitation occurred in the nannofossil claystones of early Oligocene and late Eocene but seems to be of minor importance in deeper levels. This is likely because of the lower sediment diagenetic potential (Riech and von Rad, 1979) caused by the original paucity of biogenic opal between 320 and 600 mbsf. Authigenic quartz (the final diagenetic silica product) could not be detected in SEM samples and thus is only of minor importance.

The occurrence of small amounts of opal-A (Pl. 4, Fig. 4; between 600 and $650 \mathrm{mbsf}$ ) below the level where opal-A has already been totally transformed into opal-CT may be caused by differences in host sediment environments. The opal-CT section is characterized by carbonate-rich sediments $(40 \%-50 \%)$, and the level where fragments of biogenic opal-A still exist consists of carbonate poor clayey sediments. Clays are known to retard the opal-A $\rightarrow$ opal-CT transformations (Williams et al.; 1985; Thein and von Rad, 1987).

Authigenesis of smectites is recorded in sediment Section C. The clay mineral formation was probably caused by a low-temperature combination of biogenic silica and iron oxyhydroxide during early diagenesis at a relatively shallow burial depth (Bohrmann and Thiede, this volume). Smectite growth took place at the expense of opaline silica. In early-formed carbonate precipitates, the morphology of biogenic silica was preserved as molds (Bohrmann and Thiede, this volume). In thin sections of the carbonate concretions (Pl. 5, Fig. 1), the original biogenic silica components can be estimated. These vary between 10 and 20 vol\%. Carbonate concretions revealing ghosts of siliceous biogenic components occur between 617 and $650 \mathrm{mbsf}$, which indicates higher opal concentrations, at least during that time. Because smectites are the dominant minerals of the clay mineral assemblage throughout lithologic Units III and IV (Nielsen et al., this volume), higher amounts of biogenic opal may have been present originally both above and below this interval and transformation of opaline silica to smectite may have been more widely distributed. However, the transformation process can be observed only in the interval where early carbonate precipitates occur.

\section{Paleoceanographic Implications: Estimates of Productivity from Biogenic Opal}

In two deeper intervals of Site 647 , only the alteration products of biogenic opal were detected, whereas opal-A-preserved biogenic silica could be measured in the Oligocene deposits younger than $35.5 \mathrm{Ma}$ and accumulation rates estimated (Figs. 2, 4, and 5). According to Ehrmann and Thiede (1985), average accumulation rates of opaline silica components of 100 to 500 $\mathrm{g} / \mathrm{cm}^{2} / \mathrm{m}$.y. might have been reached during the early Oligocene in the North Atlantic, which agrees well with our data, ranging to about $500 \mathrm{~g} / \mathrm{cm}^{2} / \mathrm{m} . \mathrm{y}$. at Site 647 . However, the interval between 35.5 and 34.5 Ma shows greatly enhanced opal accumulation rates of about $1200-1300 \mathrm{~g} / \mathrm{cm}^{2} / \mathrm{m}$.y. These values characterize recent deposits of the southern silica belt around the Antarctic continent (Lisitzin, 1985: 1000-1500 g/ $\mathrm{cm}^{2} / \mathrm{m}$.y.;
DeMaster, 1979: approximately $4000 \mathrm{~g} / \mathrm{cm}^{2} / \mathrm{m}$.y.) or the silicarich, Miocene Monterey Formation in the Santa Barbara Basin (Isaacs, 1985: $1900 \mathrm{~g} / \mathrm{cm}^{2} / \mathrm{m}$.y.). These areas are well-known regions of high fertility. The strongly enhanced biogenic opal accumulation around $35 \mathrm{Ma}$ at Site 647 in the Labrador Sea seems to be comparable in dimension of opal accumulation. Such a high opal production might be reached by stronger upwelling conditions. The composition of the opaline silica at that time (Table 1) was dominated by the diatom genus Pyxilla. At that time, this diatom appeared everywhere in higher latitudes where upwelling conditions are established (J. Fenner, pers. comm., 1987). Since sedimentological evidence for bottom-current activity was not found, the enrichment of this diatom up to $80 \%$ of the entire opal fraction probably was not produced by selective accumulation during current activity. Concentrations of the robust valves from Pyxilla by corrosion of other less dissolution-resistant opal particles also is not likely. A more reasonable process for enrichment is the dominant and rapid growth of the frustules in the plankton community during blooms.

Further, primary biogenic opal deposition can be detected up to approximately $41 \mathrm{Ma}$ by the record of opal-CT (Figs. 4 and 5 ). Because the formation of opal-CT is possible only when considerable amounts of biogenic opal have been buried in the sediment (Riech and von Rad, 1979; Thein and von Rad. 1987), we can assume that higher amounts of biogenic silica must have been deposited in the late Eocene (Fig. 4). Since the transformation from opal-A to opal-CT includes a dissolution step (Riech and von Rad, 1979), a portion of dissolved silica is lost by migration to other localities. Thus, we cannot estimate exactly how much opal-A was deposited initially. Assuming that opal-CT precipitation corresponds in scale to opal-A, the accumulation of biogenic silica have been somewhat lower than during the average early Oligocene. A probable higher rate of silica deposition might be recorded at the Eocene/Oligocene boundary (= maximum of opal-CT precipitation), which was certainly lower in dimension than the 35.5 to $34.5 \mathrm{Ma}$ high-silica accumulation interval.

Because of the stratigraphic dating and hiatus uncertainties, a further period of increased biogenic opal accumulation we cannot state with certainty that occurred near the lower/middle Eocene boundary (i.e., at about 53 to $47 \mathrm{Ma}$ ), in the interval of opal-A to smectite transformation (Figs. 4 and 5).

From these data, we infer that biogenic silica fertility in the surface waters of the Labrador Sea may have been enhanced during early Oligocene/late Eocene ( 41 to $30 \mathrm{Ma}$ ), with a distinct maximum between 35.5 and $34.5 \mathrm{Ma}$ (Fig. 5) and possibly during the middle/early Eocene (47 to $53 \mathrm{Ma}$ ) as well.

The occurrence of high biogenic silica contents in the Labrador Sea during Eocene time corresponds well with other studies of opal accumulation in the North Atlantic (e.g., Riech and von Rad, 1979; Fenner, 1981; Ehrmann and Thiede, 1985; Thein and von Rad, 1987). The production of biogenic opal reached a maximum during (late) early and (early) middle Eocene around 52 Ma (Riech and von Rad, 1979; Boersma et al., 1987).

The origin of silica-rich sediments in the North Atlantic is not clearly understood. Gibson and Towe (1971) postulated that volcanic matter derived from the Caribbean by winds during Eocene time would have increased dissolved silica in the water column, which may have stimulated surface-water productivity. However, extensive Caribbean volcanism also occurred during an earlier time (Mattson, 1984), so that stratigraphic restriction of the Eocene silica-rich sediments cannot be explained by temporal changes in volcanism (Tucholke and Mountain, 1986). Moreover, we believe that a higher influx of silicon from the continent to the ocean created favorable conditions for increased surface-water productivity of siliceous organisms. Warm climatic conditions and related intensive chemical weathering proba- 
bly caused higher silicon mobilization on land, as can be deduced by enhanced bauxitic and lateritic weathering during Eocene in Central Africa and South America (Valeton, 1983) and a higher influx of dissolved silica to the ocean. In connection with increased equatorial and coastal upwelling (Ramsay, 1973), this may have resulted in a broad high-fertility belt of biogenic-opalrich sediments in the North Atlantic (Thein and von Rad, 1987). Higher silicoplankton fertility also seems to be recorded in the Labrador Sea as a northwestern branch of the North Atlantic at Site 647. While during most of the middle Eocene siliceous skeletons were not found in Labrador Sea deposits, opal production seemed to increase slowly during late Eocene. This was probably caused by the cooling of surface water in late Eocene (Srivastava, Arthur, et al., 1987). A lesser maximum of opal productivity occurred at the Eocene/Oligocene boundary.

A distinct, biogenic silica accumulation maximum, reached between 35.5 and $34.5 \mathrm{Ma}$, may have resulted from upwelling. The upwelled, probably colder and silica-rich, deep water fertilized the surface layer, causing enhanced silicoplankton growth. An influence of cold (nutrient-rich ?) bottom water, probably from the Arctic Ocean via a pathway over the Baffin Bay, Lancaster Sound, and/or Nares Strait, may have been of importance.

In contrast to our data, Boersma et al. (1987), based on benthic foraminifers and $\delta^{18} \mathrm{O}$-data, imply a low primary productivity during earliest Oligocene, i.e., during times of maximum accumulation rates of biogenic opal (Fig. 5). Higher primary productivity during earliest Oligocene to middle Eocene time also is supported by increased accumulation rates of carbonate and organic carbon (Fig. 5). However, in comparison with modern high-productivity areas, such as the Peru or Namibia margins where accumulation rates of $6 \mathrm{gC} / \mathrm{cm}^{2} / \mathrm{k} . \mathrm{y} . \quad(=6000 \mathrm{gC} /$ $\mathrm{cm}^{2} / \mathrm{m}$. y.) are reached (Calvert and Price, 1983; Reimers and Suess, 1983) or the Cretaceous upwelling in the Atlantic with accumulation rates of almost $1000 \mathrm{gC} / \mathrm{cm}^{2} / \mathrm{m}$.y. (Stein et al., 1986), the Eocene accumulation rates of organic carbon of about 15 to $20 \mathrm{gC} / \mathrm{cm}^{2} / \mathrm{m}$.y. (Fig. 5) in the Labrador Sea are still very low. Although, when interpreting the organic carbon data, one must consider that the inflow of cold oxygen-rich Arctic water masses during that time may have resulted in an unusually high oxidation rate of organic matter. This may have caused the very low organic carbon values, which are unusually low for areas of higher productivity (cf. Stein et al., this volume).

\section{CONCLUSIONS}

The results of our study of biogenic silica deposition and alteration can be summarized as follows:

1. Three sections of different conditions of biogenic silica preservation can be distinguished. In Section A, higher amounts of opal-A were deposited and preserved in Miocene and early Oligocene sediments (120 to $240 \mathrm{mbsf}$ ), showing strong corrosion in the Miocene section, most probably caused by longranged hiatuses. In Section B, opal-CT was precipitated in early Oligocene to late Eocene sediments (250 to $440 \mathrm{mbsf}$ ), with maximum concentration at about 300 mbsf. And in Section C, the (late) early to (early) middle Eocene (about 620 to $650 \mathrm{mbsf}$ ) is characterized by transformation of biogenic opal into authigenic iron-rich smectites.

2. Based on accumulation rates of biogenic opal and the occurrences of opal-CT and authigenic smectites, intervals of increased opaline silica productivity may have occurred in the Labrador Sea during the early Oligocene to late Eocene, with a distinct maximum between 34.5 and $35.5 \mathrm{Ma}$ and during the lower middle Eocene.

\section{ACKNOWLEDGMENTS}

We thank reviewers P. N. Froelich, R. Marty, M. Allen, and M. Weinelt for critical discussions. For technical assistance, we thank A. Schröder, A. Brumm, A. Dettmar, D. Ortmann, R. Stax, and C. Weisner. We also thank C. Samtleben and R. Reimann for operating the SEM and U. Schuldt and S. Perbandt for photographic work. Financial support was provided by the "Deutsche Forschungsgemeinschaft" (Grant No. TH 200-3 and STE 412-1).

\section{REFERENCES}

Badaut, D., and Risacher, F., 1983. Authigenic smectite on diatom frustules in Bolivian saline lakes. Geochim., Cosmochim. Acta, 47:363375 .

Boersma, A., Premoli-Silva, I., and Shackleton, N. J., 1987. Atlantic Eocene planktonic foraminiferal paleohydrographic indicators and stable isotope paleoceanography. Paleoceanography, 2:287-331.

Bohrmann, G., 1986. Accumulation of biogenic silica and opal dissolution in upper Quaternary Skagerrak sediments. Geo. Mar. Lett., 6: $165-172$.

1988. Zur Sedimentationsgeschichte von biogenem Opal im nördlichen Nordatlantik und dem Europäschen Nordmeer (DSDP/ ODP-Bohrungen 408, 642, 643, 644, 646 \& 647). Berichte Sonderforschungsbereich 313, 9:1-221.

Broecker, W. S., and Peng, T. H., 1982. Tracers in the Sea: Palisades, NY (Eldigio Press), 1-690.

Calvert, S. E., 1974. Deposition and diagenesis of silica in marine sediments. Soc. Econ. Paleontol. Mineral. Spec. Publ., 1:273-299.

Calvert, S. E., and Price, N. B., 1983. Geochemistry of Namibian Shelf sediments. In Suess, E., and Thiede, J. (Eds.), Coastal Upwelling. Its Sediment Record, Part A: New York (Plenum Press), 337-375.

Cole, T. G., 1985. Composition, oxygen isotope geochemistry and origin of smectite in the metalliferous sediments of the Bauer Deep, southeast Pacific. Geochim. Cosmochim. Acta, 49:221-235.

DeMaster, D. J., 1981. The supply and accumulation of silica in the marine environment. Geochim. Cosmochim. Acta, 45:1715-1732.

Ehrmann, W. U., and Thiede, J., 1986. History of Mesozoic and Cenozoic sediment fluxes to the North Atlantic Ocean. Contrib. Sedimentol., 15:1-109.

Fenner, J., 1981. Diatoms in the Eocene and Oligocene sediments off northwest Africa, their statigraphic and paleogeographic occurrences [Unpublished thesis]. Univ. of Kiel, Federal Republic of Germany.

Flörke, 0. W., Jones, J. B., and Segnit, E. R., 1975. Opal-CT crystals. Neues Jahrb. Mineral. Monatsh., 369-377.

Gibson, T. G., and Towe, K. M., 1971. Eocene volcanism and the origin of Horizon A. Science, 172:152-154.

Hein, J. R., Scholl, D. W., Barron, J. A., Jones, M. G., and Miller, J., 1978. Diagenesis of late Cenozoic diatomaceous deposits and formation of the bottom simulating reflector in the southern Bering Sea. Sedimentology, 25:155-181.

Isaacs, C. M., 1985. Abundance versus rates of accumulation in finegrained strata of the Miocene Santa Barbara Basin, California. Geo. Mar. Lett., 5:25-30.

Kastner, M., 1980. Authigenic silicates in deep-sea sediments: formation and diagenesis. The Sea, 7:915-980.

Lange, H., 1982. Distribution of chlorite and kaolinite in eastern Atlantic sediments of North Africa. Sedimentology, 29:427-431.

Lauterjung, G., Will, G., and Hinze, E., 1985. A fully automatic-search program for the evaluation of Gauss-shaped diffraction patterns. Nuclear Instr. Physics Res., A239:281-287.

Leinen, M., Heath, G. R., Biscaye, P. E., Kolla, V., and Thiede, J., 1986. Distribution of biogenic silica and quartz in recent deep-sea sediments. Geology, 14:199-203.

Lisitzin, A. P., 1972. Sedimentation in the World Oceans. Soc. Econ. Paleontol. Mineral. Spec. Publ., 17:1-218.

1985: The silica cycle during the last ice age. Palaeogeogr., Palaeoclimatol., Palaeoecol., 50:241-270.

Mattson, P. H., 1984. Caribbean structural breaks and plate movements. In Bonini, W. E., Hargraves, R. B., and Shagan, R. (Eds.), The Caribbean-South American Plate Boundary and Regional Tectonics. Geol. Soc. Am. Mem., 162:131-152.

Müller, G., 1967. Methods in sedimentary petrology. In Engelhardt, W.v., Füchtbauer, H., and Müller, G. (Eds.), Sedimentary Petrology: (Schweizerbart'sche Verlagsbuchhandlung). 
Ramsay, A.T.S., 1973. A history of organic siliceous sediments in oceans. In Hughes, N. F. (Ed.), Spec. Pap. Paleontol., 12:199-234.

Reimers, C. E., and Suess, E., 1983. Late Quatenary fluctuations in the cycling of organic matter off central Peru: A protokerogen record. In Suess, E., and Thiede, J. (Eds.), Coastal Upwelling. Its Sedimentary Record, Part A: New York (Plenum Press), 497-526.

Riech, V., and von Rad, U., 1979. Silica diagenesis in the Atlantic Ocean: diagenetic potential and transformations. In Talwani, M., et al. (Eds.), M. Ewing Ser., 3:315-340.

Srivastava, S. P., Arthur, M., et al., 1987. Proc. ODP, Init. Repts., 105: College Station, TX (Ocean Drilling Program).

Stein, R., 1985. The post-Eocene sediment record of DSDP Site 366: Implications for African climate and plate tectonic drift. Geol. Soc. Am. Mem., 163:305-315.

Stein, R., Rullkötter, J., and Welte, D. H., 1986. Accumulation of organic-carbon-rich sediments in the Late Jurassic and Cretaceous Atlantic Ocean-A synthesis. Chem. Geol., 56:1-32.

Tucholke, B. E., and Mountain, G. S. 1986. Tertiary paleoceanography of the western North Atlantic Ocean. In Vogt, P. R., Tucholke, B. E. (Eds.), The Geology of North America, Vol. M, The Western Atlantic Region: Alexandria, VA (Geol. Soc. Am.), 631-650.
Thein, J., and von Rad, U., 1987. Silica diagenesis in continental rise and slope sediments off eastern North America (Sites 603 and 605, Leg 93; Sites 612 and 613, Leg 95). In Poag, C. W., Watts, A. B., et al., Init. Repts. DSDP, 95: Washington (U.S. Govt. Printing Office), 501-525.

Valeton, I., 1983. Klimaperioden lateritischer Verwitterung und ihr Abbild in den synchronen Sedimentationsräumen. Z. dt. Geol. Ges., 134:413-452.

Williams, L. A., and Crerar, D. A., 1985. Silica diagenesis, 2. General Mechanisms. J. Sediment. Petrol., 55(3):312-321.

Wolfart, R., 1982. Cretacious radiolaria from the northwest African continental margin. In Von Rad, U., et al. (Eds.), Geology of the Northwest African Continental Margin: Berlin-Hieldelberg (SpringerVerlag), 354-367.

Date of initial receipt: 31 August 1987

Date of acceptance: 21 July 1988

Ms 105B-121 


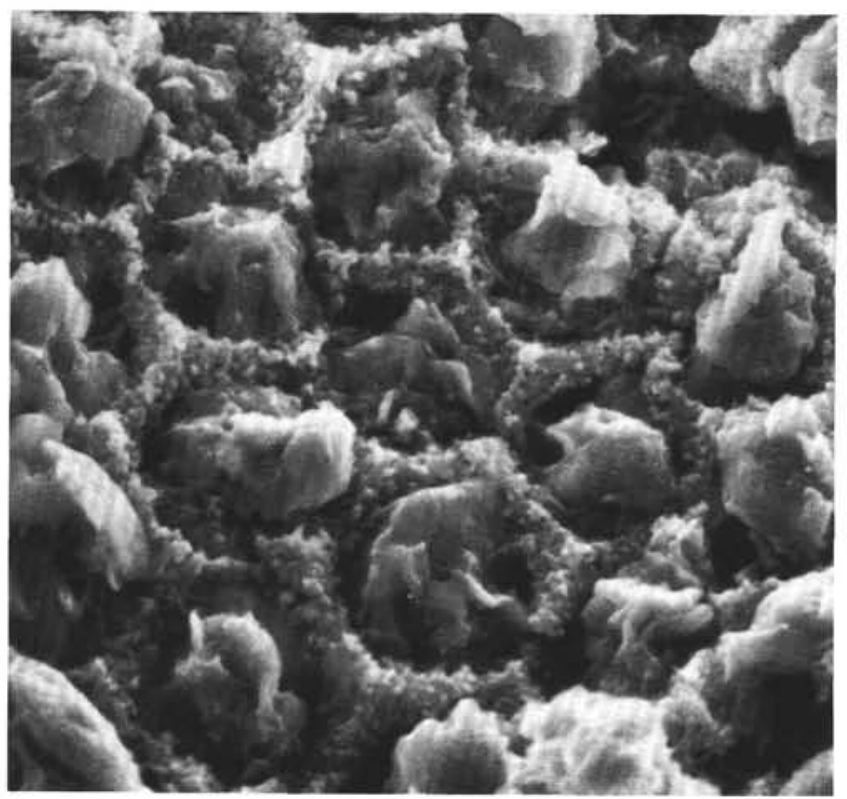

1
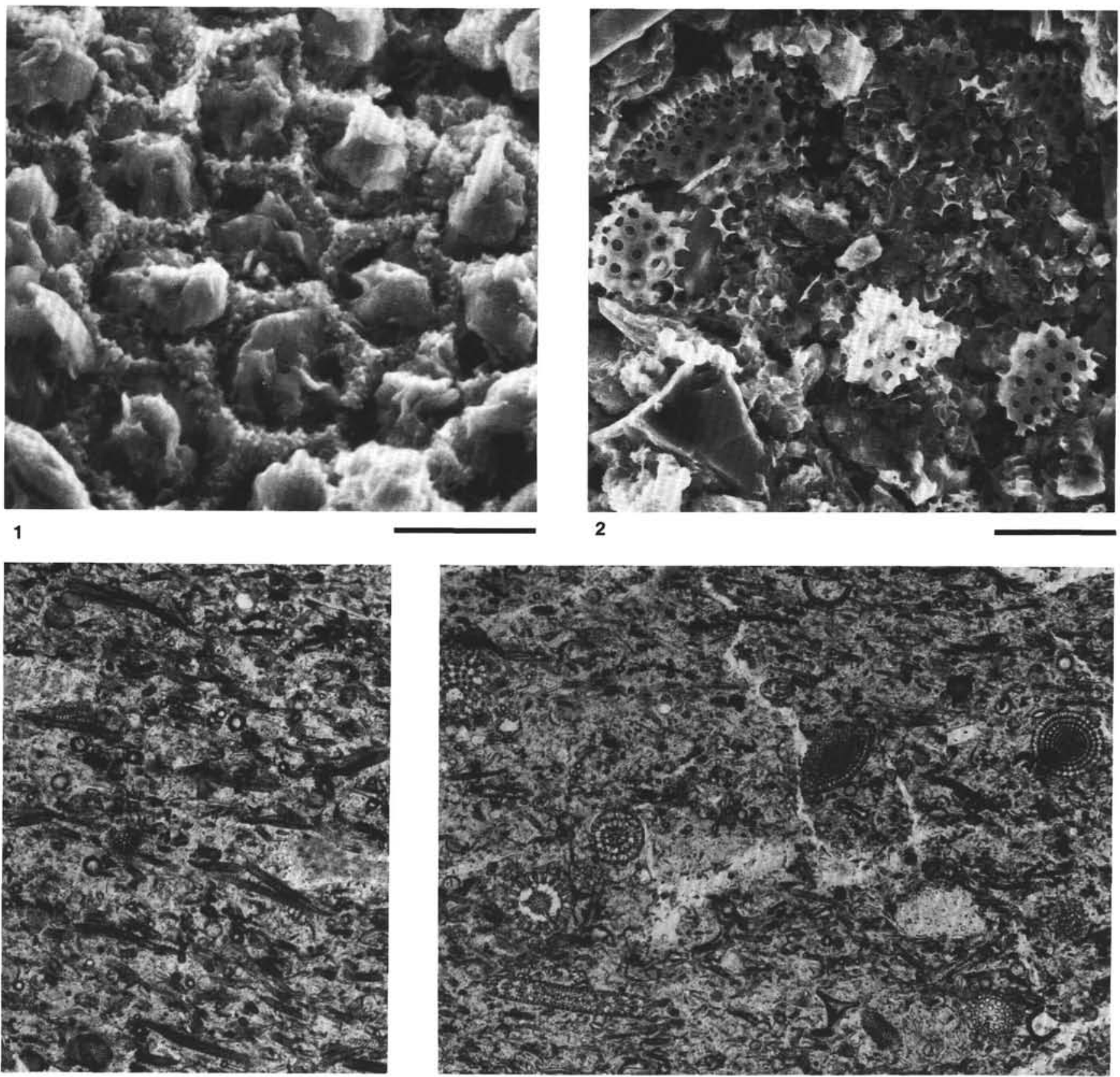

3

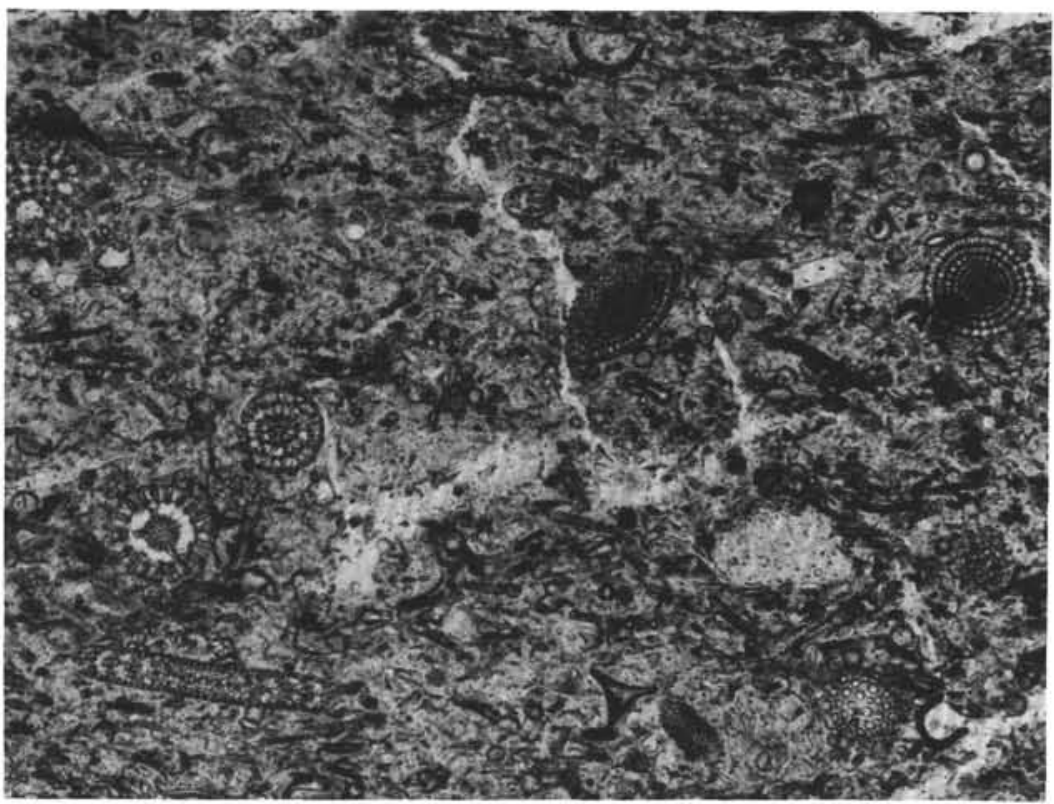

4

Plate 1. SEM pictures (1 and 2) from samples of lithologic Unit II and thin section micrographs (3 and 4) from Subunit IIIB. 1. Polygonal pattern of areolae from a strongly dissolved centric diatom valve showing very fine globulose structures of microspheres (Sample 105-647A-14R-1, 93-96 cm; scale bar $=4 \mu \mathrm{m}$ ). 2. Fragmentation of diatom frustules by dissolution (Sample 105-647A-13R-5, 63-66 cm; scale bar $=20 \mu \mathrm{m}$ ). 3. Thin section slice vertical to bedding showing the longish frustules of Pyrgupyxis oriented parallel to stratification (Sample 105-647A-24R-4, $51-53 \mathrm{~cm}$; scale bar $=200 \mu \mathrm{m})$. 4. Thin section micrograph from a radiolarian-rich layer (Sample $105-647 \mathrm{~A}-24 \mathrm{R}-4,51-53 \mathrm{~cm} ; \mathrm{scale}$ bar $=300$ $\mu \mathrm{m})$. 


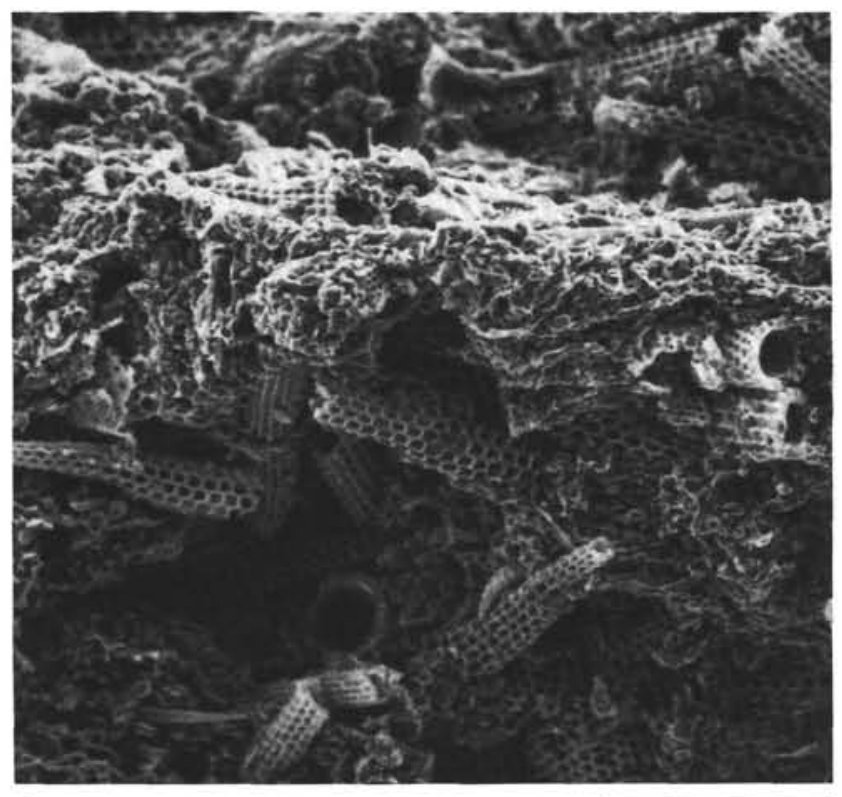

1

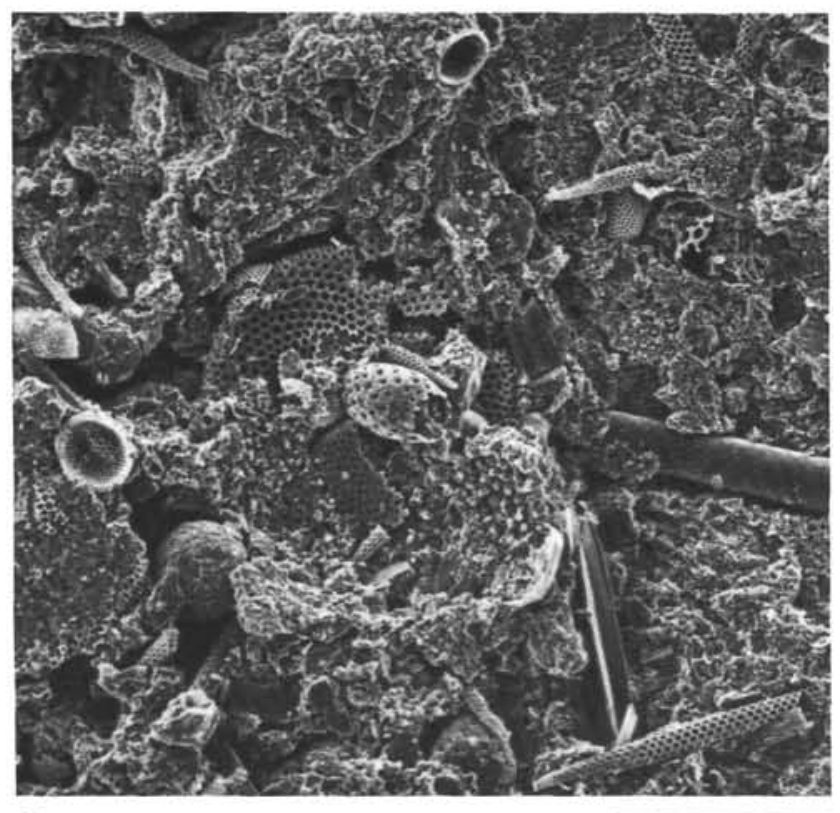

3

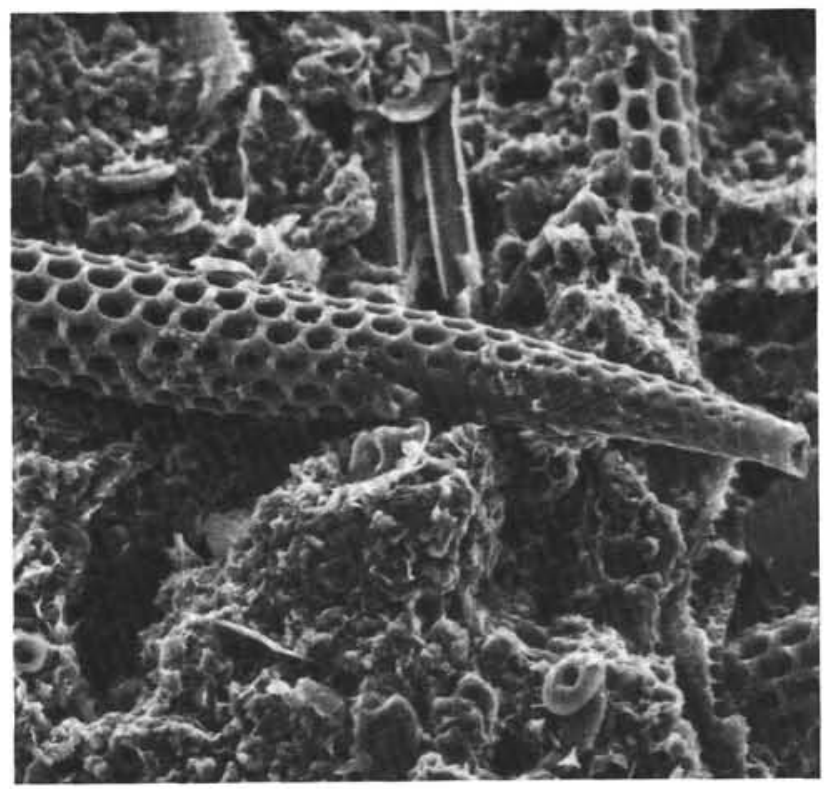

2

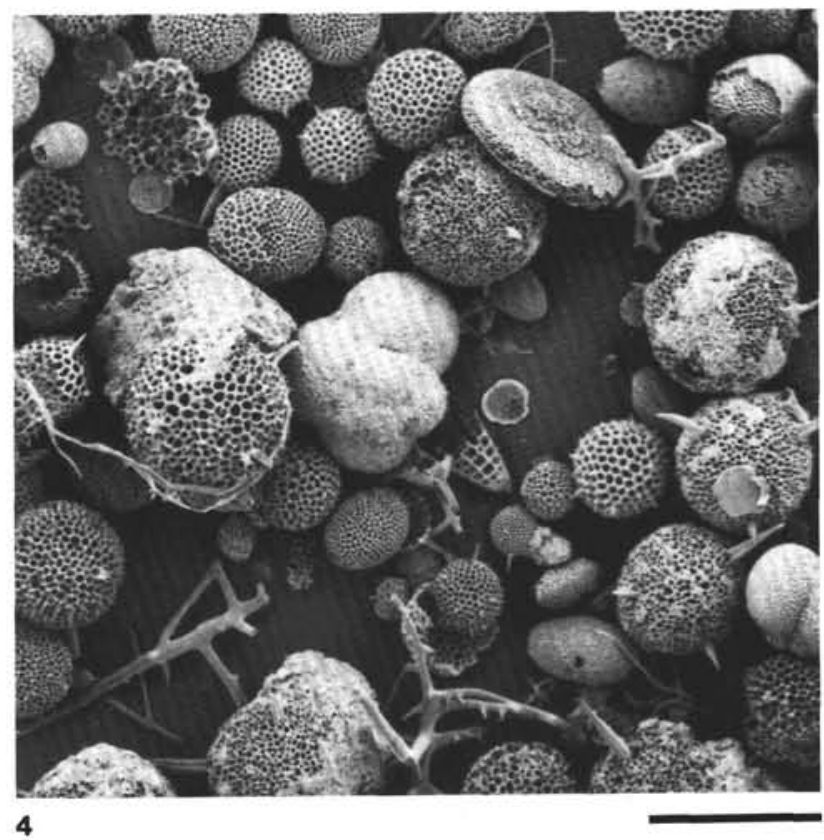

Plate 2. SEM pictures from lithologic Subunit IIIB. 1. Sediment layer dominated by the elongated valves of the diatom Pyrgupyxis that were imbedded parallel to stratification (Sample 105-647A-24R-4, 51-54 cm; scale bar $=40 \mu \mathrm{m}$ ). 2. Detail of a specimen of Pyrgupyxis showing heavily silicified valves (Sample 105-647A-24R-4, 51-54 cm; scale bar $=20 \mu \mathrm{m}$ ). 3. Biogenic opal composed of different organism groups (Sample 105-647A-24R-4, 51-54 cm; scale bar $=100 \mu \mathrm{m}$ ). 4. Coarse fraction of Subunit IIIB is dominated by radiolarians (Sample 105-647A-18R-1, 99-101 cm; scale bar $=400 \mu \mathrm{m})$. 


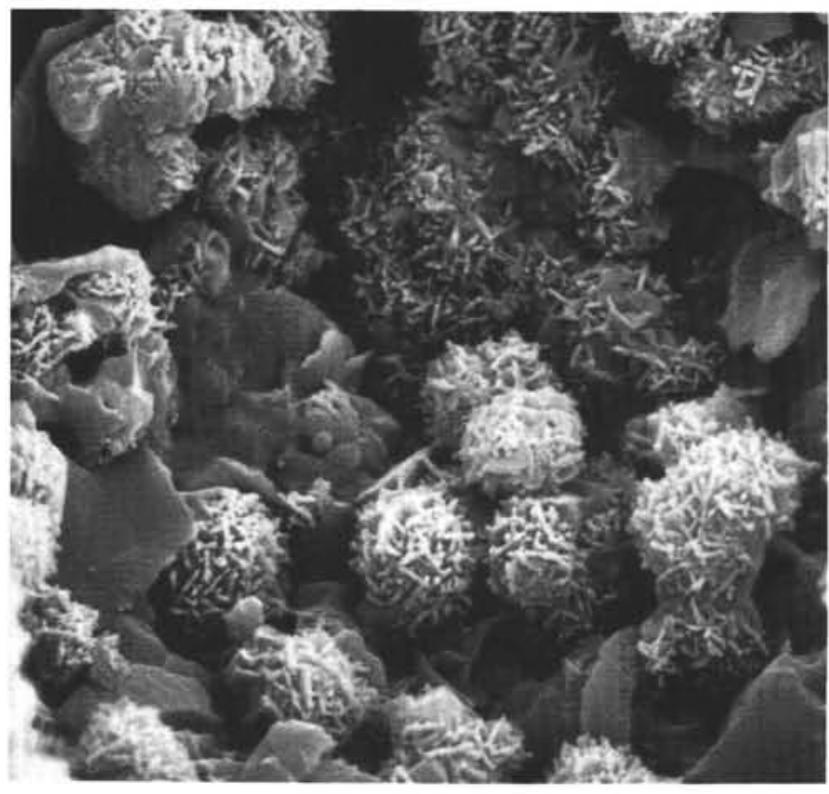

1

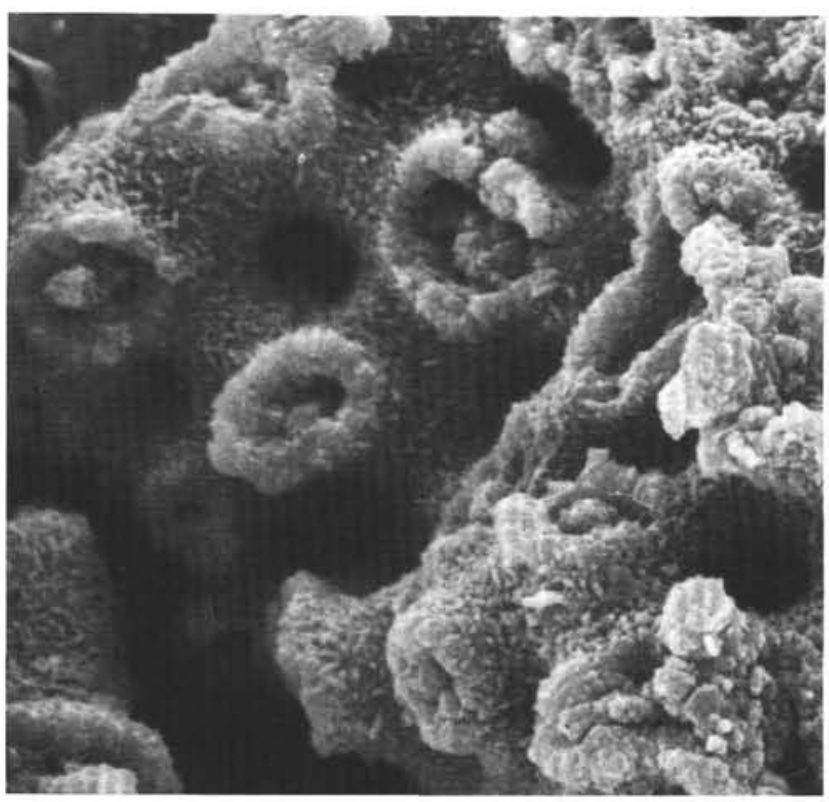

3

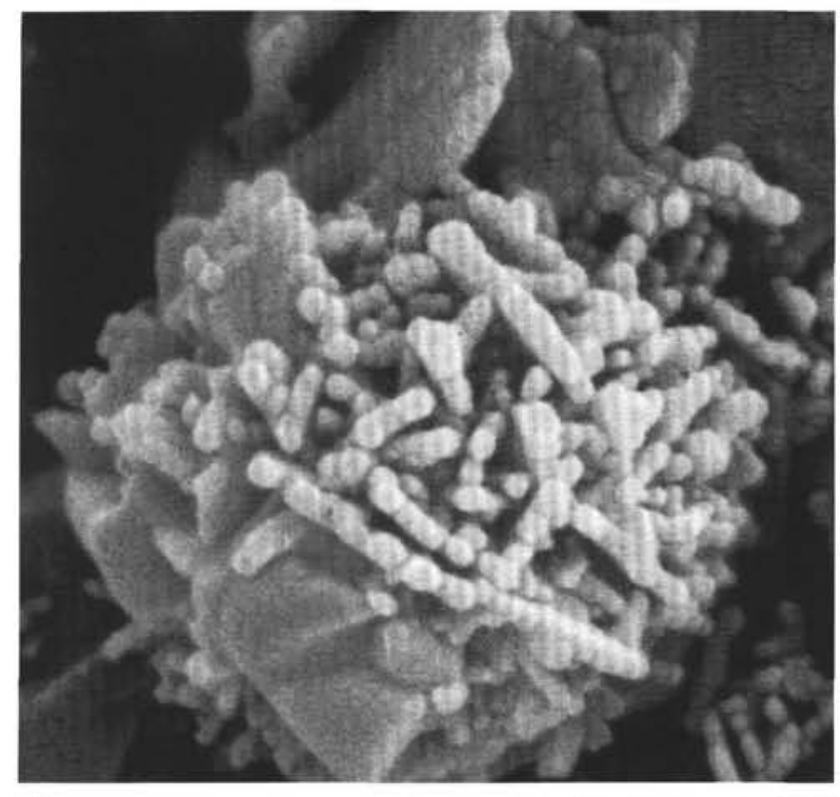

2

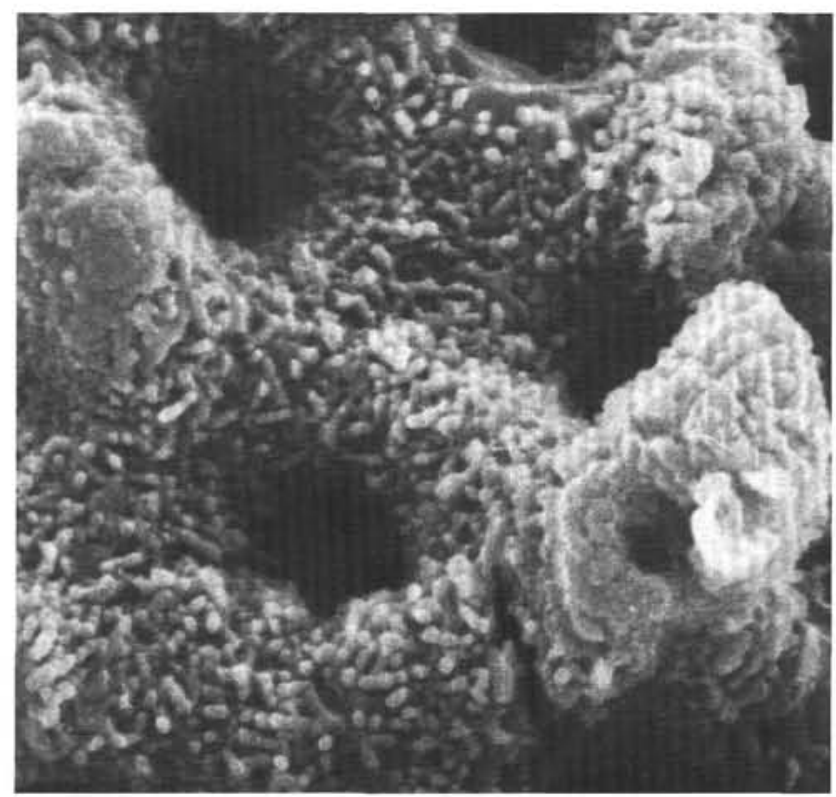

4

Plate 3. SEM pictures from sediment samples of Subunit IIIC. 1. Opal-CT lepispheres growing in the interior of a calcareous test (Sample 105647A-32R-2, 24-28 cm; scale bar $=4 \mu \mathrm{m})$. 2. Individual lepisphere of very thin opal-CT blades $(0.1 \mu \mathrm{m}$ thick) showing irregular ragged edges (Sample 105-647A-32R-2, 24-28 cm; scale bar $=1 \mu \mathrm{m}$ ). 3. Detail of a radiolarian skeleton showing the original skeletal opal-A replaced by bladed opal-CT (Sample 105-647A-31R-2, 55-59 cm; scale bar $=4 \mu \mathrm{m}$ ). 4. Detail of Fig. 3 showing a network of very fine intertwinned ellipsoidal opal-CT blades, resulting from in-situ replacement of skeletal opal-A by opal-CT (Sample 105-647A-31R-2, 55-59 cm; scale bar $=2 \mu \mathrm{m}$ ). 

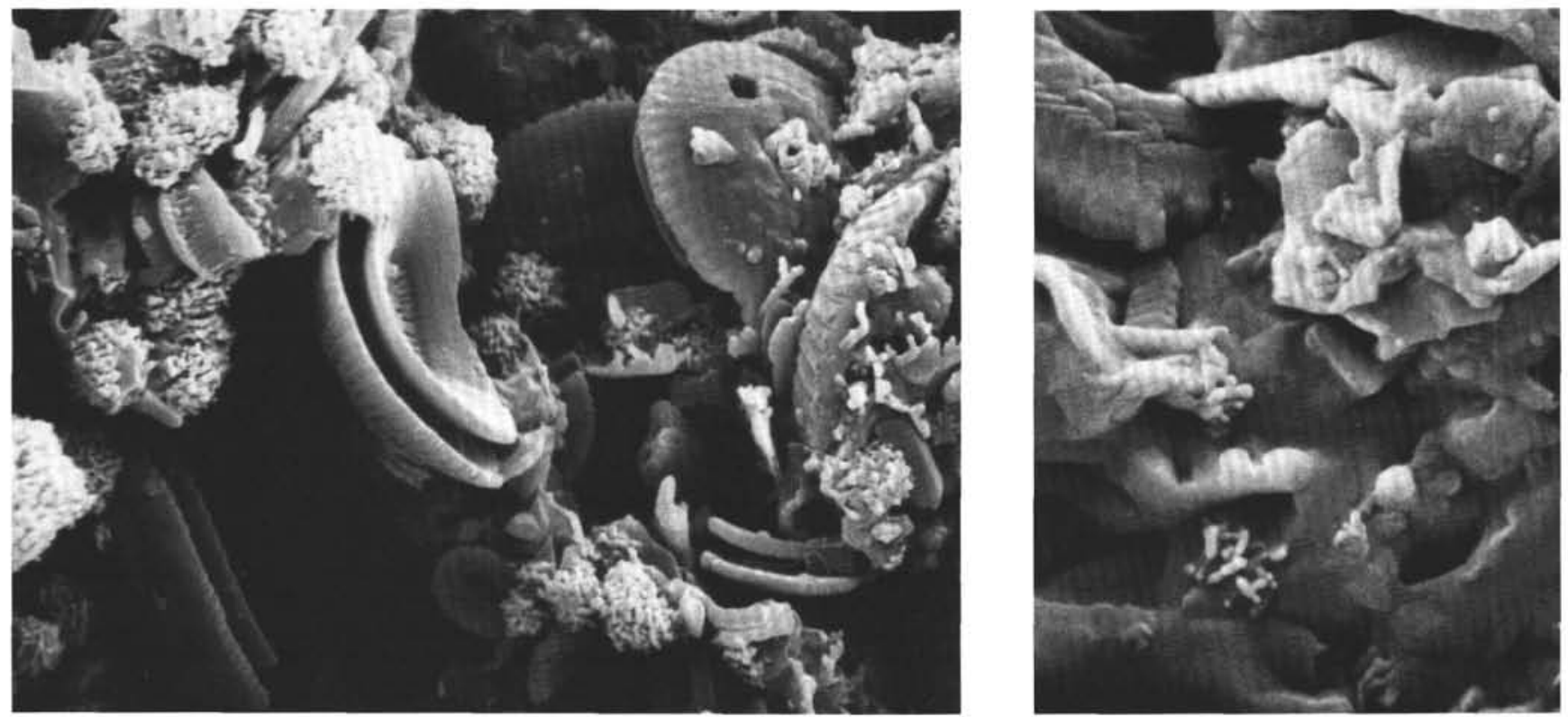

1

2

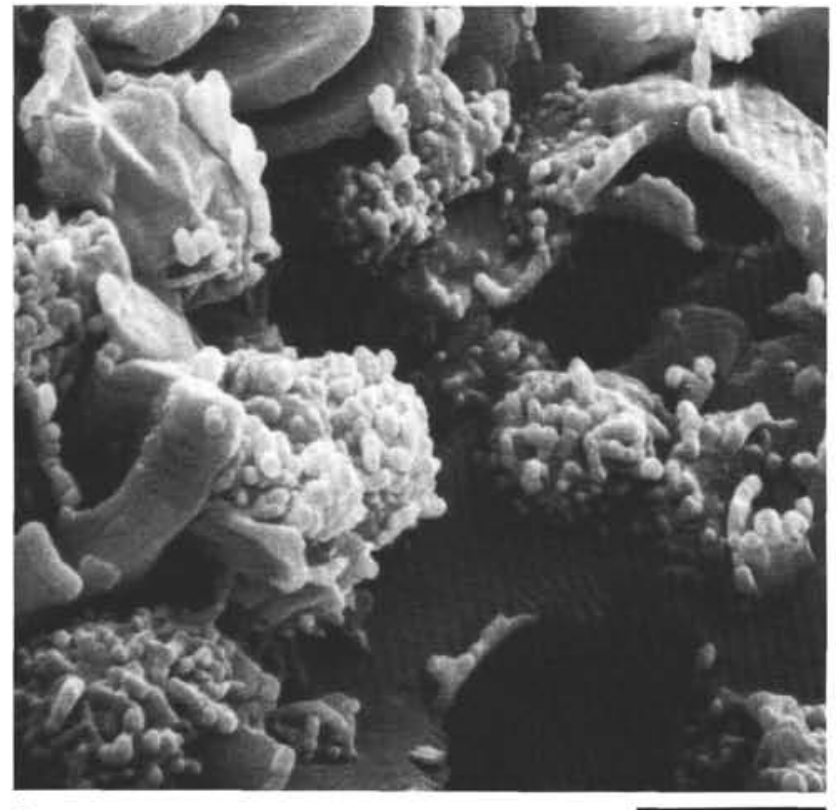

3

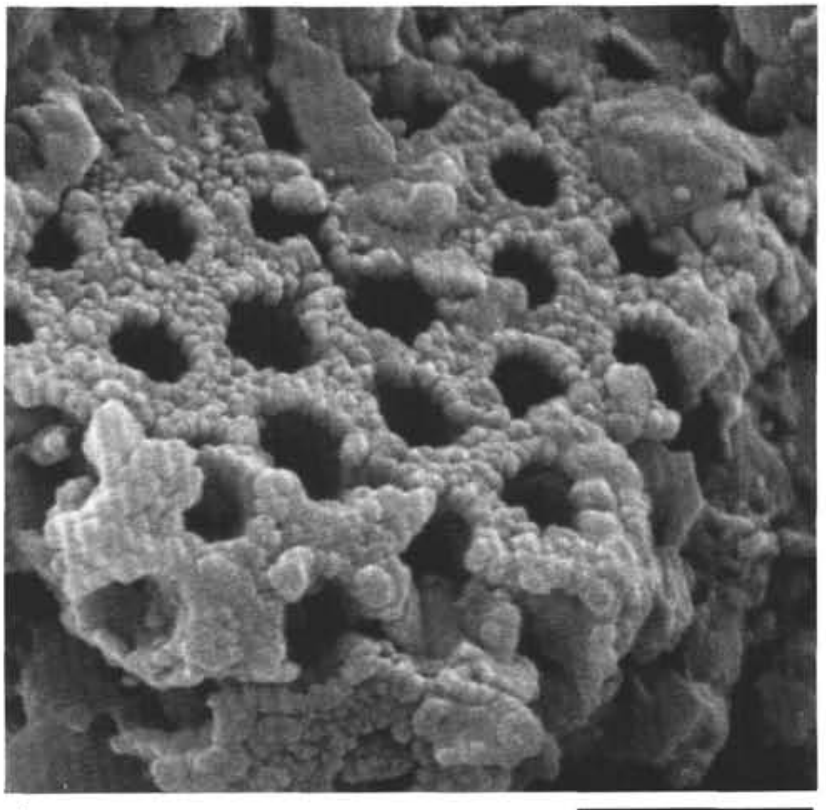

4

Plate 4. SEM pictures from Subunit IIIC (1-3) and Unit IV (4) 1. Scattered opal-CT lepispheres grown on calcareous nannofossils (Sample 105-647A-33R-1, 62-65 cm; scale bar $=4 \mu \mathrm{m})$. 2. Initial growth of an opal-CT lepisphere in the pore space (Sample 105-647A-33R-2, 59-61 cm; scale bar $=2 \mu \mathrm{m}$ ). 3. Partly vermiculelike opal-CT blades forming irregular lepispheres (Sample 105-647A-33R-1, 62-65 cm; scale bar $=2 \mu \mathrm{m}$ ). 3. Strongly dissolved biogenic opal of a diatom frustule (Sample 105-647A-64R-1, 94-96 cm; scale bar $=2 \mu \mathrm{m}$ ). 


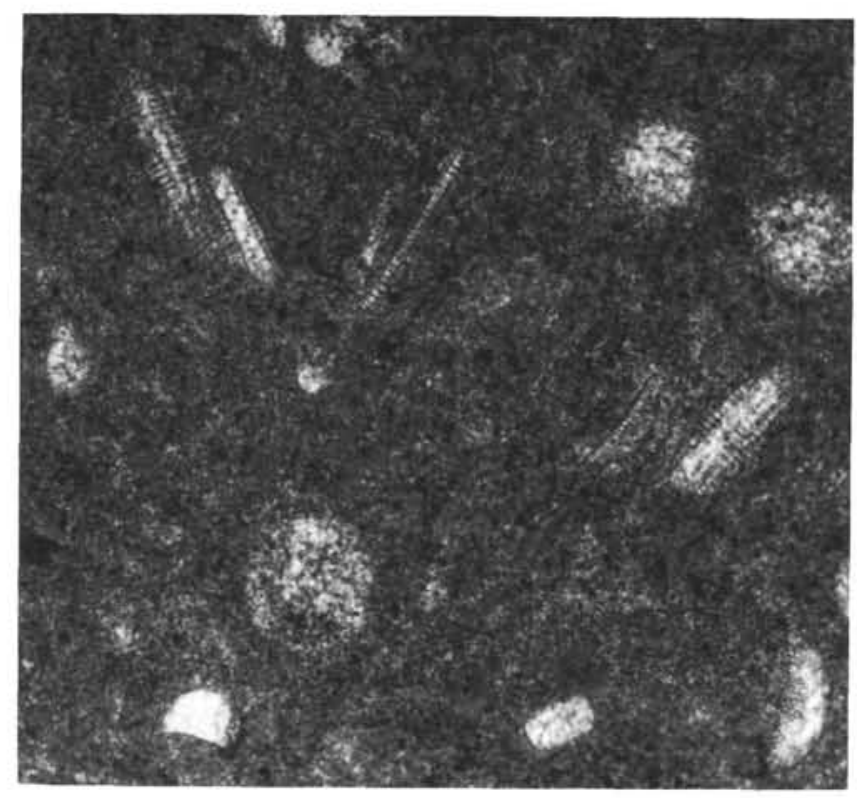

1
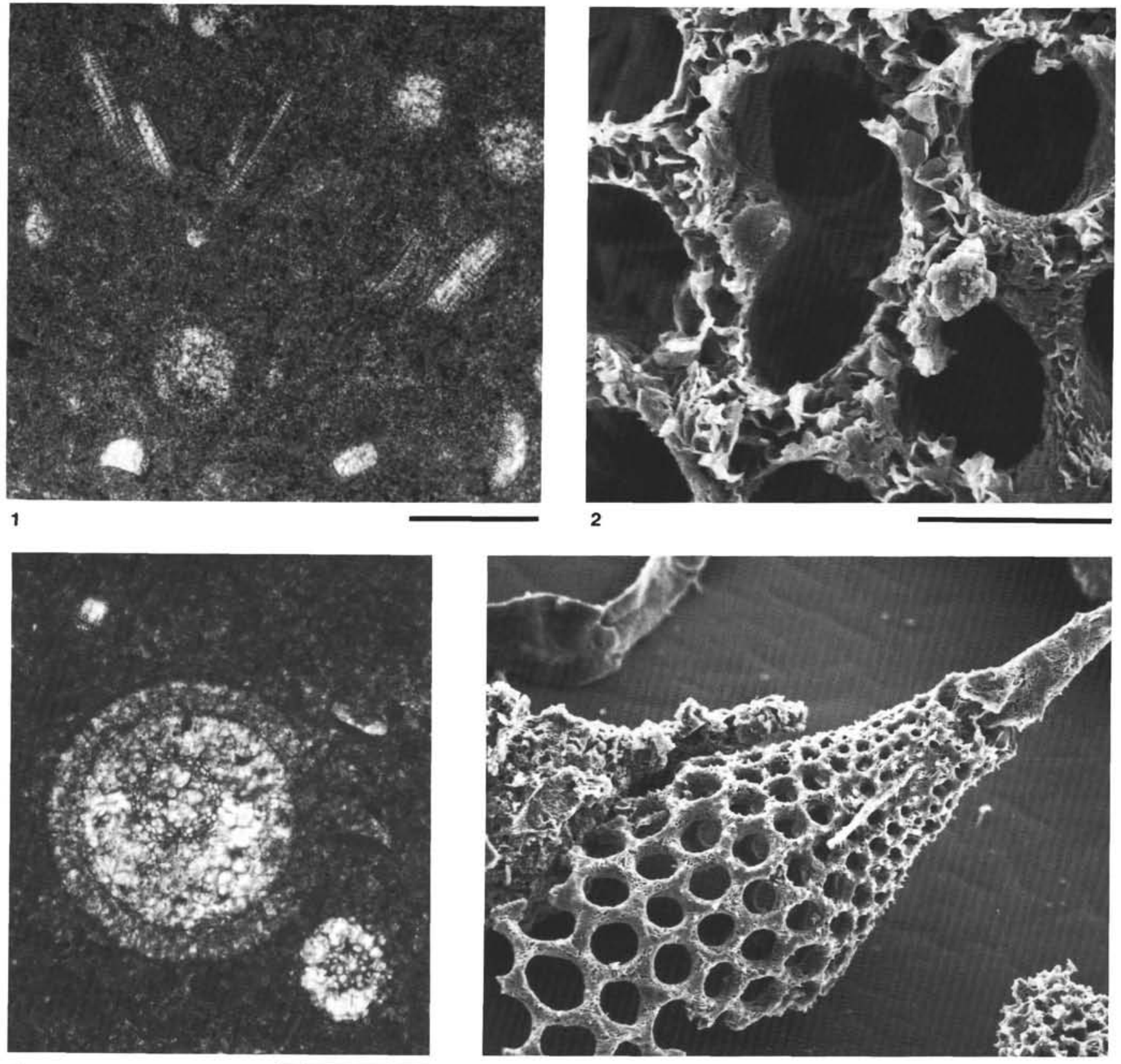

3

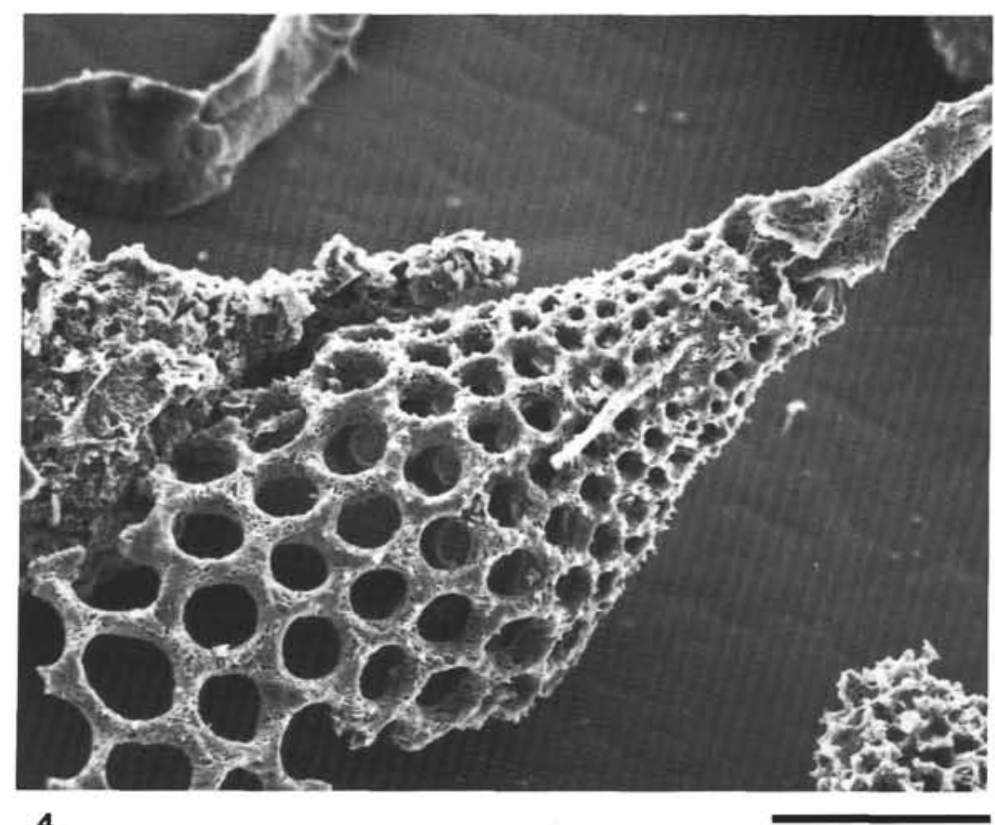

Plate 5. Thin section (1 and 3) and SEM micrographs (2 and 4) from lithologic Unit IV. 1. Thin section from an early cemented carbonate concretion showing the original abundance of diatoms and radiolarians (Sample 105-647A-67R-2, 46-48 cm; scale bar $=100 \mu \mathrm{m}$ ). 2. Detail of a radiolarian from the the acid-residue showing skeletal opal-A replaced by smectite minerals (Sample 105-647A-67R-1, 122-125 cm; scale bar = 10 $\mu \mathrm{m})$. 3. Ghosts of radiolarians imbedded in authigenic carbonate (Sample 105-647A-67R-2, 46-48 cm; scale bar $=150 \mu \mathrm{m}$ ). 4 . Radiolarian skeleton showing totally converted opal-A to authigenic clay minerals (Sample 105-647A-67R-1, 122-125 cm; scale bar $=40 \mu \mathrm{m}$ ). 